\title{
Bacteria in sea ice and underlying water of the eastern Weddell Sea in midwinter
}

\author{
Elisabeth Helmke, Horst Weyland
}

Alfred-Wegener-Institute for Polar and Marine Research, PO Box 120161, D-27515 Bremerhaven, Germany

\begin{abstract}
Bacteria in the water beneath the sea ice of the eastern Weddell Sea were homogeneously distributed. Direct counts resembled values from spring and autumn, whereas viable cell counts, total ATP concentrations, as well as heterotrophic assimilation and extracellular enzymatic activities were very low, implying a metabolic inactive bacterioplankton. The consolidated sea ice had a very heterogeneous horizontal distribution of microbes on large as well as small scales but vertical profiles in low and densely populated ice cores exhibited similar patterns. A close relation between bacterial colonization of sea ice and genetic ice classes was revealed. Sea ice of the 'predominantly congelation ice' had the lowest bacterial biomass and displayed very low heterotrophic activities which were comparable to those of the water column. Samples of older sea ice belonging to the 'mainly frazil' and 'mixed ice' had maximal numbers of bacteria. They often included high proportions of culturable cells and dividing cells as well as large bacteria. The bacteria of these ice classes were active and contributed significantly to the productivity in the Weddell Sea during winter. 'Predominantly frazil ice' was less colonized; however, selective bacterial growth was also indicated in this typical winter ice by an increase in the proportions of culturable and psychrophilic bacteria with advancing age of the ice. Psychrophilic bacteria dominated in consolidated sea-ice whereas facultative psychrophiles prevailed in young sea-ice and water, corroborating a strict partitioning in a microbial sea-ice and a seawater regime. Generally, temperature does not appear to be the significant factor for the development of bacterial communities in the surface layer of the eastern Weddell Sea in winter since the metabolically active bacterial flora develops in the very cold sea-ice environment. The organic matter supply and its improved usability obviously controls bacterial activity as well as the selective enrichment of psychrophiles.
\end{abstract}

KEY WORDS: Bacteria $\cdot$ Sea ice $\cdot$ Winter $\cdot$ Antarctica $\cdot$ Weddell Sea

\section{INTRODUCTION}

The Southern Ocean is characterized by a very large seasonal fluctuation of ice cover ranging from about 4 to $20 \times 10^{6} \mathrm{~km}^{2}$ (Zwally et al. 1983). Despite the transient existence of most of the Antarctic sea ice, it nevertheless provides a vast habitat for a variety of organisms, mainly diatoms, bacteria, flagellates, and protozoa, which reside within the internal brine pocket system (for reviews see Horner 1985, Garrison et al. 1986, Horner et al. 1992, Palmisano \& Garrison 1993). Studies during the last decade have established that algae of sea-ice communities contribute significantly to the primary productivity of the polar seas (literature compiled by Palmisano \& Garrison 1993), despite the multitude of environmental stress factors such as low temperature and irradiance coupled with high salinities. Bacterial production within the sea ice was also demonstrated (Grossi et al. 1984, Sullivan et al. 1985, Kottmeier \& Sullivan 1987, 1990, Kottmeier et al. 1987, Rivkin et al. 1989, Grossmann \& Dieckmann 1994) and there is evidence of a functioning microbial loop (Kottmeier et al 1987, Garrison \& Buck 1989, Kottmeier \& Sullivan 1990). Most of the extensive studies of the bacterial component of Antarctic sea-ice communities have taken place during spring, autumn, and summer. They focussed on bacterial abundance, biomass, and growth activities but some studies also dealt with the diversity, taxonomical and physiological characterization, as well as nutritional requirement of sea-ice bacteria (Delille 1992, Zdanowski \& Donachie 1993). However, to evaluate the role of bacteria in the sea ice of the Antarctic Ocean and to understand their seasonal importance, more information is needed particularly on winter sea ice which comprises the major 
part of pack ice. Due to the difficulties in accessing winter ice, studies of the bacterial sea-ice flora during this season are scarce. A limited data set is available from the fast ice including associated water of the McMurdo Sound (Kottmeier et al. 1985, Rivkin et al. 1989) as well as near Syowa station (Satoh et al. 1989) and from the marginal pack-ice zone of the Weddell Sea (Marra et al. 1982, Garrison \& Close 1993). The most extensive bacteriological winter study was conducted in the diffusive pack ice west off the Antarctic Peninsula (Kottmeier \& Sullivan 1987). However, the sea-ice situation there is quite different from that of the central, open-ocean pack-ice region of the eastern Weddell Sea.

Within the framework of the 'Winter Weddell Sea Project 1986' (WWSP 86), an international, multidisciplinary program, the cruise ANT V/2 of the icebreaking RV 'Polarstern' provided an opportunity to study the microbial community across the entire width of the annual sea-ice cover of the Weddell Sea in midwinter. We focussed on the bacterial components of the sea-ice and underlying water biota and investigated their distribution and biomass as well as metabolic state and activity, in order to contribute to the understanding of the seasonal dynamics and role of microheterotrophs in annual sea-ice communities.

\section{MATERIALS AND METHODS}

Ice situation and sampling. During the cruise ANT V/2 of the RV 'Polarstern' the sea ice in the open Weddell Sea was traversed (Fig. 1) in the vicinity of the $0^{\circ}$ meridian from the ice edge $\left(\sim 59^{\circ} \mathrm{S}\right)$ southward close to the continental shelf ice $\left(\sim 69^{\circ} \mathrm{S}\right)$, and to the ice edge at $\sim 56^{\circ} \mathrm{S}$ on the return journey, in the period July 18 to September 10, 1986. Detailed information about ice situation, ice structure, and ice history is given by Casarini \& Massom (1987), Wadhams et al. (1987), and Lange et al. (1989, 1990). Lange et al. (1989) defined 5 genetic ice classes which are indicative of the history of sea-ice formation and evolution. The classification of the ice cores into genetic ice classes related to the proportions of the 3 textural ice classes: granular ice, columnar ice, and mixed granular/columnar ice. Ice cores representing the predominantly and mainly frazil ice contained more than 80 or $60 \%$ granular ice, respectively; predominantly and mainly congelation ice cores contained more than 80 or $60 \%$ columnar ice, respectively; mixed frazil/congelation ice cores contained more than $40 \%$ of both granular and columnar ice. The ice classes of the ice cores studied are given in Fig. 1. Raabe (1987) described the weather and synoptic situation during ANT V/2. Temperatures within the sea ice ranged from $-15^{\circ} \mathrm{C}$ at the top to about $-2.5^{\circ} \mathrm{C}$ at the bottom of the ice cover (Bartsch 1989). Brine salin- ities ( $178 \%$ top to $35 \%$ bottom) are a function of temperature and can be calculated from brine temperature by the equations of Assur (1958). Bulk salinities are indicative of vertical brine movement and therefore of the age of the floe. During ANT V/2, mean values of $10.6 \%$ in the upper ice layers and of $5.4 \%$ in the bottom layers were determined (Bartsch 1989).

Ice cores from consolidated ice, chunks of brown coloured ice, samples of grease ice, young pancake ice, and underlying water were taken along the route (Fig. 1). Chunks of ice as well as grease ice and young pancake ice were collected by means of a wire net. Ice cores were drilled with a modified SIPRE ice auger ( $7.5 \mathrm{~cm}$ diameter). The ice cores used for bacteriological examination were taken close to those cores sampled for the assessment of ice structure, physical, chemical, and biological properties (Bartsch 1989, Lange et al. 1989, 1990, Spindler et al. 1990, Dieckmann et al. 1991a, b). Due to the small-scale patchiness

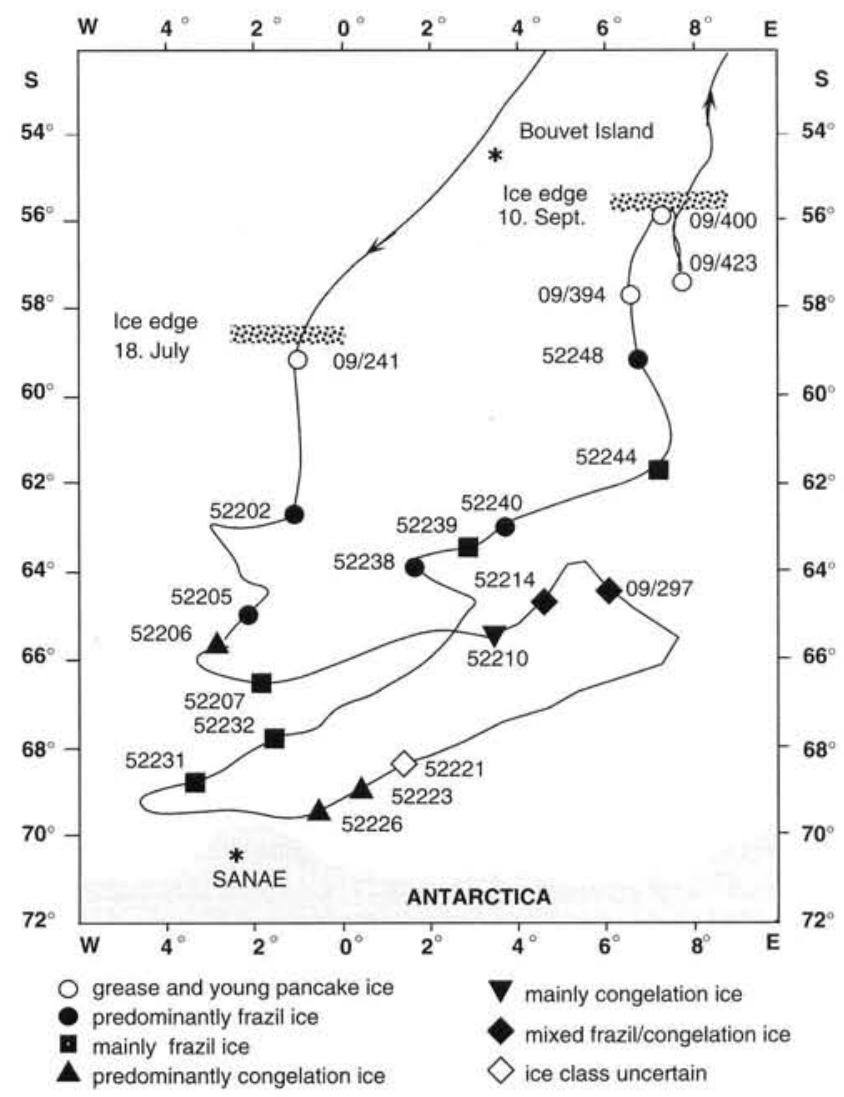

Fig. 1. Location of bacteriological sampling stations in the eastern Weddell Sea during the Winter Weddell Sea Project 1986 (WWSP 86) cruise ANT V/2 of RV 'Polarstern'. Sea-ice core stations are numbered with the first digits 52 . Grease and small pancake ice as well as chunks of brown ice were sampled at the locations numbered with the first digits 09 . The genetic ice classes of the cores are indicated by different symbols 
of the sea ice, parallel cores may differ considerably. Nevertheless, to simplify the comparison between the different data sets, the bacteriological ice cores were numbered just as the parallel cores. Careful attention was paid to maintain sterile conditions during sampling and subsequent processing. The bacteriological cores were cut into $10 \mathrm{~cm}$ sections which were often subdivided into $2 \mathrm{~cm}$ sections. Unless stated otherwise the ice sections as well as the other ice samples were mechanically crushed and melted in measured volumes of filtered $(0.2 \mu \mathrm{m}$ pore size) autoclaved seawater (ratio seawater to sea ice 1:1, final salinities 20 to $23 \%$ ). The ice had melted within $1 \mathrm{~h}$.

Seawater underlying the pack ice was pumped manually with a plastic bilge pump which had been rinsed with $95 \%$ ethanol and flushed several times with seawater from the sampling site. Ice-core drilling holes served as sampling sites. Surface seawater from the marginal ice zone was collected with sterile glass bottles $(500 \mathrm{ml})$. Seawater from greater depth was taken with 101 Niskin bottles on a rosette sampler.

Total bacterial counts and bacterial biomass. Seaice and water samples were fixed with formalin $(3 \%$ final concentration) and stored at $2^{\circ} \mathrm{C}$ prior to enumeration. Bacteria were enumerated by epifluorescence microscopy according to the acridine orange direct count method (AODC) of Hobbie et al. (1977). The microscopic counting and sizing was carried out in the home laboratory $3 \mathrm{mo}$ after sampling; due to vibration and movement of the ship, this work was not conducted aboard directly after sampling.

Bacterial cell concentrations were determined at least from each $10 \mathrm{~cm}$ section of an ice core. Biovolumes were estimated from 3 to 6 selected sections per core. Bacterial cell volumes were grouped into size classes which correspond to average nominal volumes of: $0.065 \mu^{3}$ (small cocci, diameter $0.5 \mu \mathrm{m}$ ); $0.39 \mu^{3}$ (short rods, diameter $0.7 \mu \mathrm{m}$, length $1.0 \mu \mathrm{m}$ ); $0.58 \mu \mathrm{m}^{3}$ (medium rods, diameter $0.6 \mu \mathrm{m}$, length $2.0 \mu \mathrm{m}$ ); $1.33 \mu^{3}$ (long rods, diameter $0.65 \mu \mathrm{m}$, length $4.0 \mu \mathrm{m}$ ). The volume of rods longer than $4 \mu \mathrm{m}$ were individually calculated. To convert cell volumes to carbon, a factor of $220 \mathrm{fg} \mathrm{C}_{\mu \mathrm{m}^{-3}}$ (Bratbak 1985) was used. The bacterial organic carbon was multiplied with the conversion factor of 0.004 (Karl 1980) to obtain values of bacterial ATP.

ATP. For measurements of particulate ATP concentrations, volumes of 50 to $100 \mathrm{ml}$ of the various sea-ice (immediately after melting) and water samples were filtered through Nuclepore filters $(0.2 \mu \mathrm{m}$ pore size). The particulate material of some densely populated ice-core sections were size fractionated by passing $100 \mathrm{ml}$ of melted ice through $12.0 \mu \mathrm{m}, 3 \mu \mathrm{m}$, and $0.2 \mu \mathrm{m}$ pore size Nuclepore filters in succession. The filters were extracted in TRIS-buffer after Holm-Hansen (1973). Extracts were stored frozen at $-27^{\circ} \mathrm{C}$ prior to analysis. ATP was assayed with the ATP-luciferase test combination HS (Boehringer) and the ATP-biophotometer SAI model 3000.

Viable counts. The number of culturable heterotrophic bacteria was estimated by the most probable number (MPN) technique as well as by the spread plate and membrane filtration method. For MPN calculations, 3 replicates of successive 10 -fold dilutions were prepared using ZoBell medium 2216E with $100 \%$ seawater content (SW).

The number of colony forming units (CFU) was determined by spreading $0.1 \mathrm{ml}$ of the original sample or the decimal dilutions onto the surface of Chitin agar (Weyland et al. 1970). Furthermore $1 \mathrm{ml}, 10 \mathrm{ml}$, or $100 \mathrm{ml}$ sample volumes, respectively, were filtered onto membrane filters $(0.1 \mu \mathrm{m}$ pore size, mixed esters of cellulose, Schleicher \& Schuell) and these were also placed onto Chitin agar. Chitin medium yielded from our experience higher CFUs than the commonly used ZoBell agar. In order to obtain indications about the salinity tolerance of sea-ice and water bacteria, the medium was applied at 3 different salinity concentrations: Chitin agar $100 \%$ SW prepared with $100 \%$ natural seawater, Chitin agar 0\%SW with $100 \%$ distilled water, and Chitin agar $300 \%$ SW with $100 \%$ natural seawater plus $46.0 \mathrm{~g} \mathrm{NaCl}, 1.4 \mathrm{~g} \mathrm{KCl}$, and $10.6 \mathrm{~g}$ $\mathrm{MgCl}_{2} \cdot 6 \mathrm{H}_{2} \mathrm{O}, 3.0 \mathrm{~g} \mathrm{CaCl}_{2} \cdot 2 \mathrm{H}_{2} \mathrm{O} \mathrm{I}^{-1}$.

The susceptibility of the bacterial ice flora to the reduction of the osmotic pressure occurring during ice melting was tested by thawing replicate ice samples from 4 different stations as follows: (1) without seawater addition (final salinity 5 to $10 \%$ ); (2) with an equivalent volume of sterile, particle-free seawater (final salinity 20 to $23 \%$ ). Aliquots of both preparations were spread on Chitin agar $100 \%$ SW to assess viable bacterial counts.

Samples and cultures were not exposed to temperatures exceeding $4^{\circ} \mathrm{C}$ during the different operation steps. After 3 to 4 mo incubation at $1{ }^{\circ} \mathrm{C}$, colonies were counted and growth of the MPN replicates evaluated by turbidity. Vials with very low or no turbidity were examined microscopically. MPNs were calculated according to statistical tables (Rodina 1972).

Organisms and temperature tolerance. Pure cultures for taxonomical and ecophysiological studies were obtained from colonies which developed on solid media. The isolated strains were maintained on ZoBell agar 2216 E $(75 \%$ SW $)$ at $1^{\circ} \mathrm{C}$.

Temperature tolerance of these strains was studied in liquid ZoBell medium $2216 \mathrm{E}$ at $0,5,10,15,18,24$, and $30^{\circ} \mathrm{C}$. For growth determination at $-5^{\circ} \mathrm{C}$ and growth rate calculations the ZoBell medium 2216E was supplemented with $1 \%$ glycerol. The ability of organisms to grow at the different temperatures was examined by means of turbidity measurements at $590 \mathrm{~nm}$ with a Mul- 
tiskan plus MK II (Flow Laboratories). Direct counts were used for growth rate calculations (see Fig. 8). According to Morita (1975) psychrophiles are defined by growth at or below $0^{\circ} \mathrm{C}$, optimum $<15^{\circ} \mathrm{C}$, maximum $<20^{\circ} \mathrm{C}$. Psychrotrophs (facultative psychrophiles) are characterized by growth at or below $0^{\circ} \mathrm{C}$, optimum $>15^{\circ} \mathrm{C}$, maximum $>20^{\circ} \mathrm{C}$. Instead of the term psychrotrophs we use the term facultative psychrophiles.

Turnover times and bacterial production. Turnover times of dissolved organic material (DOM) were estimated by ${ }^{3} \mathrm{H}$-leucine as well as ${ }^{14} \mathrm{C}$-glucose uptake. Consolidated sea ice is a heterogeneous physical environment composed of several distinct microenvironments with partly separated substrate pools, therefore, the influence of sea-ice preparation on turnover times was tested. The following 4 sea-ice preparations were applied: (1) small ice cubes soaked with labelled substrate; (2) small ice cubes suspended in sterile, filtered seawater (ratio seawater to ice 1:1), plus tracer; (3) sea ice completely melted in seawater (ratio seawater to ice 1:1), plus tracer; and (4) melted ice without seawater addition, plus tracer.

The heterotrophic utilization of dissolved substrates was determined by the tracer approach (Williams \& Askew 1968) with final concentrations of 0.4 to 0.5 nmol $1^{-1} \mathrm{~L}-\left[4,5{ }^{3} \mathrm{H}\right]$ leucine (sp. act. $1.74 \mathrm{TBq} \mathrm{mmol}^{-1}$, Amersham) and 7.1 to $11.6 \mathrm{nmol} 1^{-1} \mathrm{D}$-[U- $\left.{ }^{14} \mathrm{C}\right]$-glucose (sp. act. $10 \mathrm{GBq} \mathrm{mmol}^{-1}$, Amersham). Uptake rates were measured as a function of time to establish linearity. Eight replicates were prepared using Method 2. At the beginning of the experiment, 2 of the replicates (blanks) were melted and poisoned with $\mathrm{HgCl}_{2}$ (final concentration $7.7 \mu \mathrm{mol} 1^{-1}$ ). The remaining samples were incubated at $-2^{\circ} \mathrm{C}$ in the dark and reactions were stopped after 6,12 , and $18 \mathrm{~h}$. Cells were collected on cellulose nitrate filters (pore size $0.2 \mu \mathrm{m}$ ), rinsed with particle-free seawater and subsequently assayed for radioactivity by liquid scintillation spectrometry in a Beckman LS-1000C with Filtercount (CanberraPackard) as scintillation medium. Quenching was determined by the external standard ratio method.

To differentiate between the heterotrophic activity of bacteria and eukaryotes, replicate activity experiments were treated with the antibiotics D-threo-chloramphenicol (final conc. $300 \mu \mathrm{g} \mathrm{ml}^{-1}$; Serva) and cycloheximide (final conc. $3 \mathrm{\mu g} \mathrm{ml}^{-1}$; Sigma), respectively, according to Marten \& Brandt (1984).

Rates of heterotrophic bacterial production were determined according to Fuhrman \& Azam (1982) using [methyl $-{ }^{3} \mathrm{H}$ ] thymidine (sp. act. $2.81 \mathrm{TBq} \mathrm{mmol}^{-1}$, Amersham) at a final concentration of $5 \mathrm{nmol}^{-1}$. Bacterial production experiments were performed similar to the assimilation experiments described above but cells were collected on Nuclepore filters (pore size 0.2 $\mu \mathrm{m})$ and extracted with ice-cold $5 \%$ trichloroacetic acid (TCA). Thymidine uptake was converted to bacterial cell production using a factor of $2.05 \times 10^{18}$ cells $\mathrm{mol}^{-1}$ of thymidine incorporated (Riemann et al. 1982). Bacterial carbon production was calculated using the mean bacterial cell volume of the sample and the conversion factor $220 \mathrm{fg} \mathrm{C}_{\mathrm{gm}}{ }^{-3}$.

Extracellular enzyme activity. Activities of extracellular enzymes in ice and water samples were examined by means of dissolved fluorogenic model substrates after Hoppe (1983): leucine-methylcoumarinylamide (leu-MCA) for aminopeptidases; methylumbelliferylphosphate (MUF-phos.) for phosphatases; methylumbelliferyl- $\alpha-\mathrm{D}$-glucopyranoside (MUF- $\alpha$-gluc.) for $\alpha$-glucosidases; and methyl- $\beta-D-$ glucopyranoside (MUF- $\beta$-gluc.) for $\beta$-glucosidases. Fluorescence was determined at $365 \mathrm{~nm}$ excitation and $455 \mathrm{~nm}$ emission by means of the spectrofluorophotometer SFB-23/B Kontron Instruments. The enzymatic tests were carried out with 10 to $15 \mathrm{ml}$ of sea ice (melted without seawater) or seawater. To estimate the maximum hydrolysis velocity $\left(V_{\max }\right), 4$ different substrate concentrations in the range of 1 to $26 \mu \mathrm{mol} \mathrm{l^{-1 }}$ were used. The enzymatic activities were determined at $1^{\circ} \mathrm{C}$, except the hydrolysis rates of the ice core no. 52221 (see Table 6) which were done at $20^{\circ} \mathrm{C}$ due to extremely low activites.

\section{RESULTS}

\section{Total bacterial counts and biomass}

A large-scale patchy horizontal distribution of organisms in the pack ice was evident from visual inspections of overturned ice floes which showed a strong variation in the degree of discolouration by algae. Discrepancies in the biological features were, however, also apparent in the range of 1 to a few meters, as evidenced by measurements of adjacent cores.

Counts of bacteria within the ice ranged over 4 orders of magnitude (Fig. 2). Sea ice with bacterial cell concentrations not exceeding $1 \times 10^{5}$ bacterial cells $\mathrm{ml}^{-1}$ (ice core nos. 52 202, 52 205, 52 238, 52 240, 52 248) predominated in the northern part of the study area and represented the 'predominantly frazil ice'. Elevated bacterial cell concentrations were determined in 'older sea ice' (term according to Dieckmann et al. 1991a) with discoloured zones belonging to the 'mainly frazil' and 'mixed frazil/congelation ice class' (Lange et al. 1989) (core nos. 52 207, 52 214, 52 231, $52232,52239,52244$ ). This densely populated sea ice was found mainly in the south of the study area (Fig. 1). 'Predominantly congelation ice' (core nos. 52 206, 52 226) representing refrozen leads (nilas ice) had the lowest bacterial concentrations. 

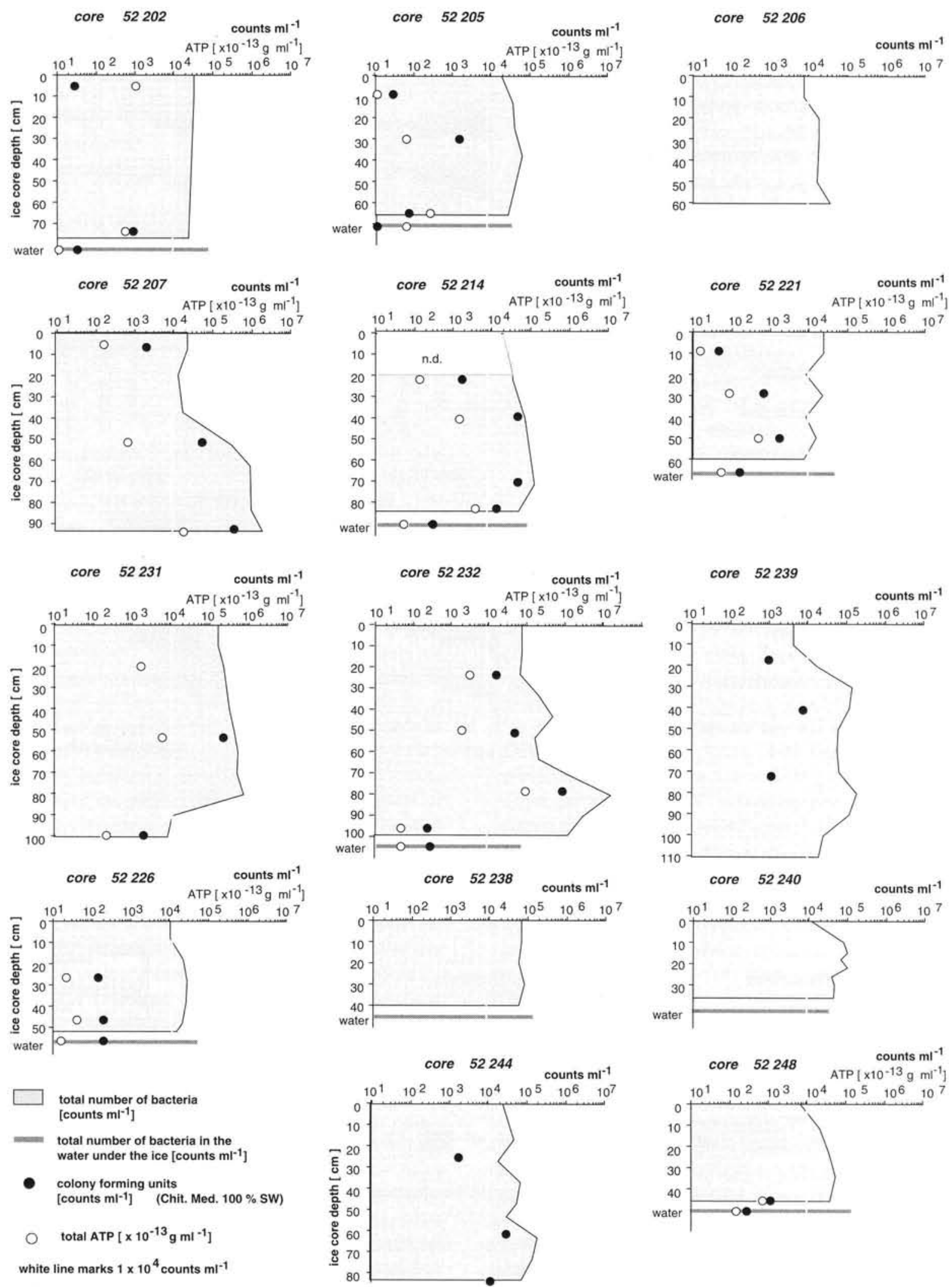

Fig. 2. Total counts of bacteria in sea ice and underlying water in comparison to colony forming units of bacteria and total ATP concentrations 
core 52202

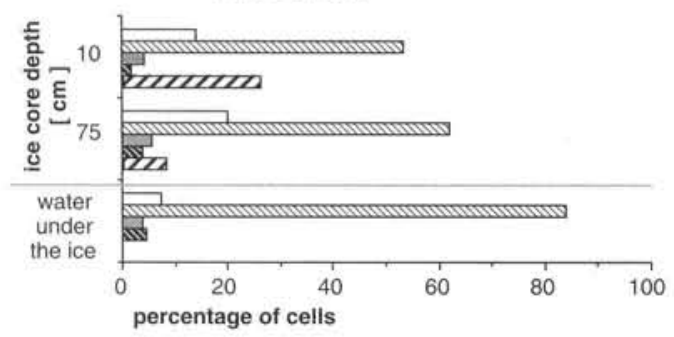

core 52221

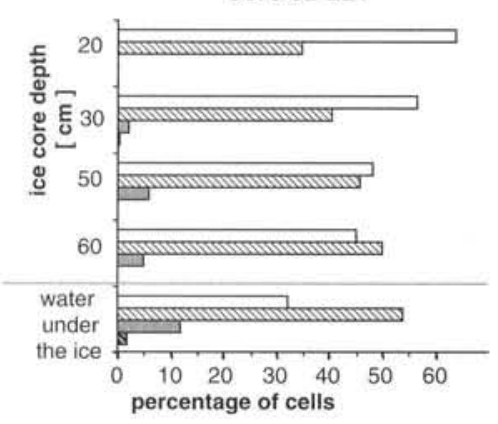

core 52226
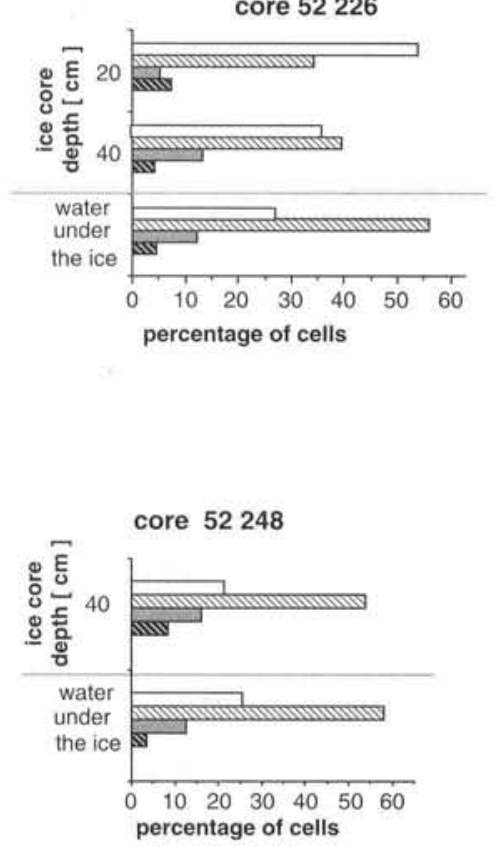

size classes core 52207

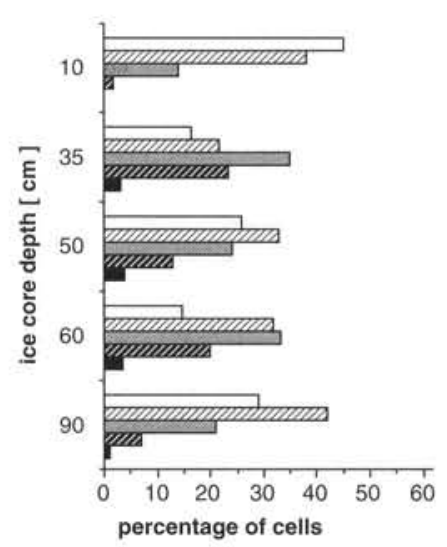

core 52231

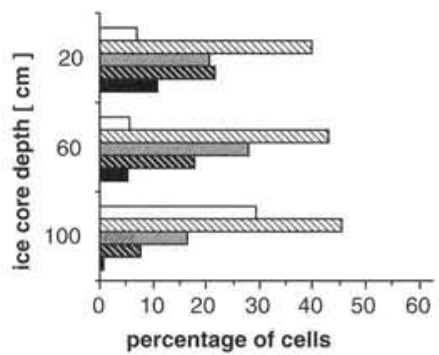

core 52214

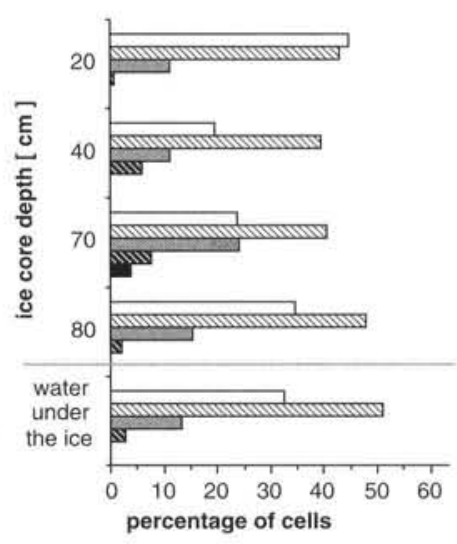

core 52232

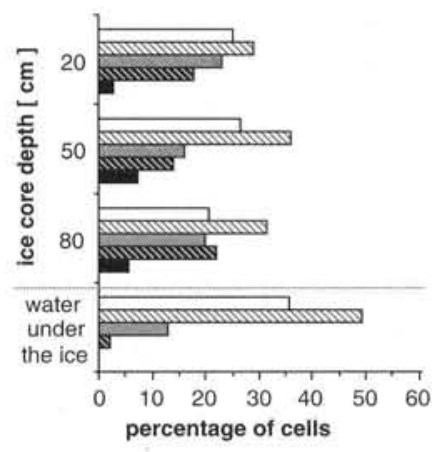

Ice edge stations

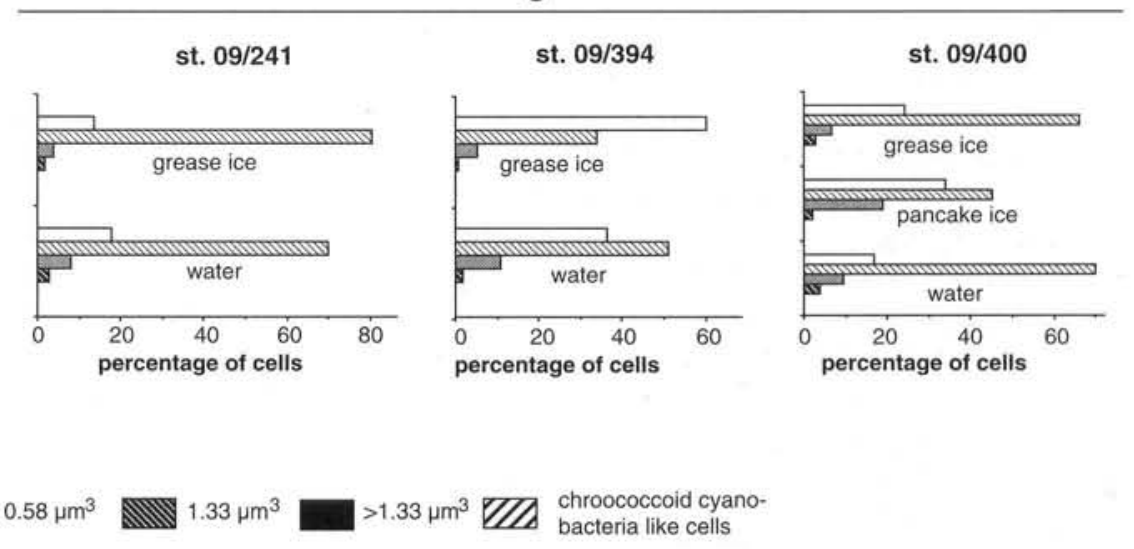

Fig. 3. Size pattern of bacterial sea-ice and water assemblages

The vertical distribution of bacteria throughout the ice displayed a rather uniform pattern with interior ice assemblages (for a description of different ice assemblages see Horner et al. 1992). Bacterial cell concentrations attained their maximum between about 10 to
$30 \mathrm{~cm}$ above the bottom of the sea ice. The maximum cell concentration of bacteria was $1.8 \times 10^{7}$ cells $\mathrm{ml}^{-1}$. Nearer to the bottom, bacterial cell concentrations were lower but lowest densities (minimum $4 \times 10^{3}$ cells $\mathrm{ml}^{-1}$ ) were determined in the upper zone at the 


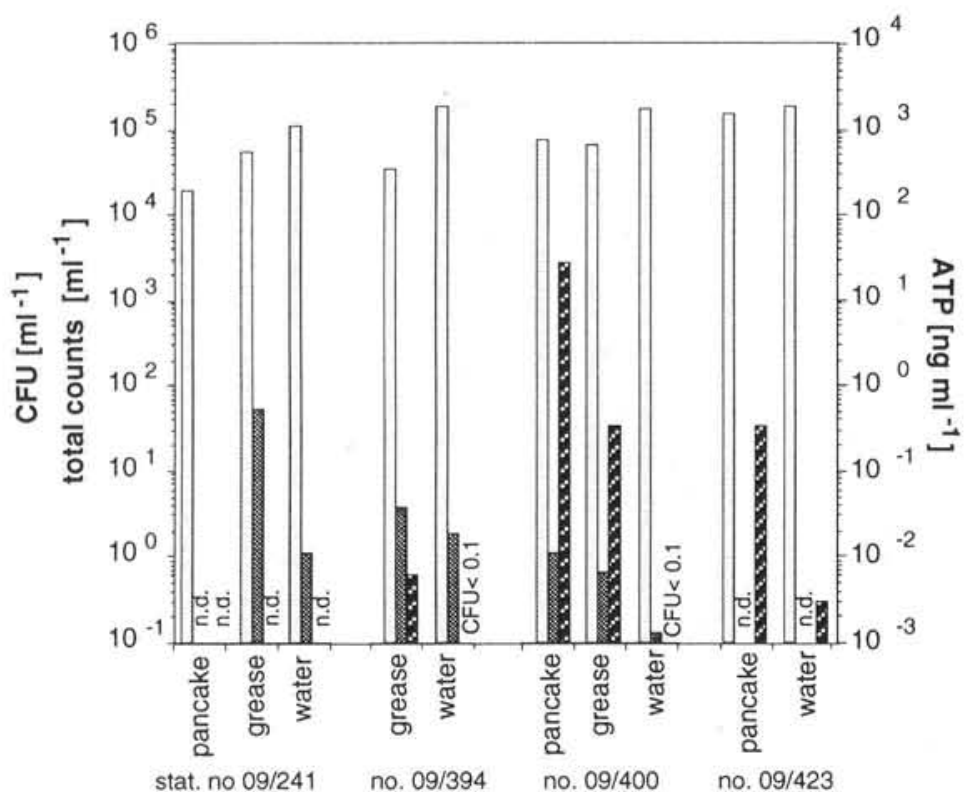

total number of bacteria

colony forming units of bacteria (CFU) n.d. = not determined

Fig. 4. Total counts and colony forming units of bacteria as well as total ATP concentrations in young sea-ice and water samples of the ice edge area

activity of these bacterial communities. The electron micrographs exhibit a variety of distinct morphological bacterial types including different epiphytic bacteria with appendages (Fig. 5F, G, H) as well as organisms with slime sheath (Fig. 5D). Slime formation appeared as a very common property (about $20 \%$ ) among the sea-ice isolates.

Total bacterial biomass calculated on the basis of bacterial cell concentration and cell volume is compared to ATP (index of total living biomass ) in Table 1 . The bacterial biomass in the water beneath the ice had a low scatter similar to that of the bacterial cell concentration. In spite of the small cell volumes of the bacterioplankton, their biomass integrated over $100 \mathrm{~m}$ water depth exceeded, in any case, the integrated biomass in the sea ice above, even if densely populated sea-ice floes with larger bacterial cells were considered.

\section{ATP concentrations}

The ATP concentration of particles greater than $0.2 \mu \mathrm{m}$ was determined as an index for

snow/ice interface. Although an accumulation of chroococcoid cyanobacteria-like cells were found in the upper part of the sea-ice core 52202 (Fig. 3), a development of pond and infiltration communities was otherwise not evident during this season.

The patchy horizontal distribution in the sea ice was not reflected in the underlying water column. Bacterial densities in the water beneath the ice cover ranged from 0.4 to $2 \times 10^{5}$ cells $\mathrm{ml}^{-1}$ (Figs. $2 \& 4$ ). The higher cell concentrations were found in the marginal ice zone where the bacterial density in the water always surpassed that in the young grease or pancake ice (Fig. 4). In the water column the vertical gradient of the bacterial cell concentration was small. The total number of bacteria averaged $5 \times 10^{4}$ cells ml-1 to a depth of $25 \mathrm{~m}$ and $2 \times 10^{4}$ cells $\mathrm{ml}^{-1}$ to a depth of $1000 \mathrm{~m}$.

The size patterns of different bacterial assemblages from sea ice and water are demonstrated in Fig. 3. The seawater samples and all sea-ice habitats with low bacterial concentrations had smaller cells with mean cell volumes of 0.17 to $0.35 \mu^{3}$. Brown coloured, densely populated ice cores were inhabited by high proportions of exceptionally large bacterial cells. Organisms longer than $10 \mu \mathrm{m}$ and with a diameter exceeding $1 \mu \mathrm{m}$ (Fig. 5A, B, C) were frequently encountered. In some of these middle ice-core sections, average cell volumes increased up to $0.9 \mu^{3}$. High proportions of dividing cells up to $6 \%$ (Fig. 5C, E) as well as flagellated cells (Fig. 5D, E) indicate in situ living biomass of all the biota. Total particulate ATP in the sea-ice samples ranged from $2 \mathrm{ng}^{-1}$ in nilas ice and upper ice-core sections to a maximum of $9520 \mathrm{ng}$ $\mathrm{1}^{-1}$ in a brown, near-bottom ice layer (Fig. 6). Assuming a carbon to ATP ratio of 250:1 (Karl 1980), the total living biomass ranged from 0.5 to $2380 \mu \mathrm{g} \mathrm{C} 1^{-1}$.

Total particulate ATP concentrations in the water column under the sea ice changed little and ranged from $<1$ to $6 \mathrm{ng} \mathrm{l}^{-1}$ (Fig. 6), i.e. $<0.25$ to $1.5 \mu \mathrm{g} \mathrm{Cl}^{-1}$. A slight increase of total ATP up to $20 \mathrm{ng} \mathrm{l}^{-1}$ was observed in the water at the ice edge and south up to $59^{\circ}$ latitude, with the exception of Stn 09/400 (Fig. 6).

In contrast to the bacterial biomass, ATP in sea ice integrated over the ice-core depth was always higher than that of the underlying water integrated over an equivalent depth (Table 1). At 3 stations, even more ATP was found in the $1 \mathrm{~m}$ ice layer than in the $100 \mathrm{~m}$ water column beneath.

ATP concentrations in relation to viable and total bacterial counts are presented in Figs. $2 \& 4$. The low ATP concentrations of all water and most upper icecore samples correspond with viable rather than with total bacterial counts. If ATP is compared with calculated bacterial ATP, all water, some upper ice-core samples, and the samples of ice core 52226 ('predominantly congelation ice') differed from the remaining ice samples (Fig. 6). In the former cases, calculated bacterial ATP exceeded measured total ATP, indicating that the conversion factor is much too high. As the 


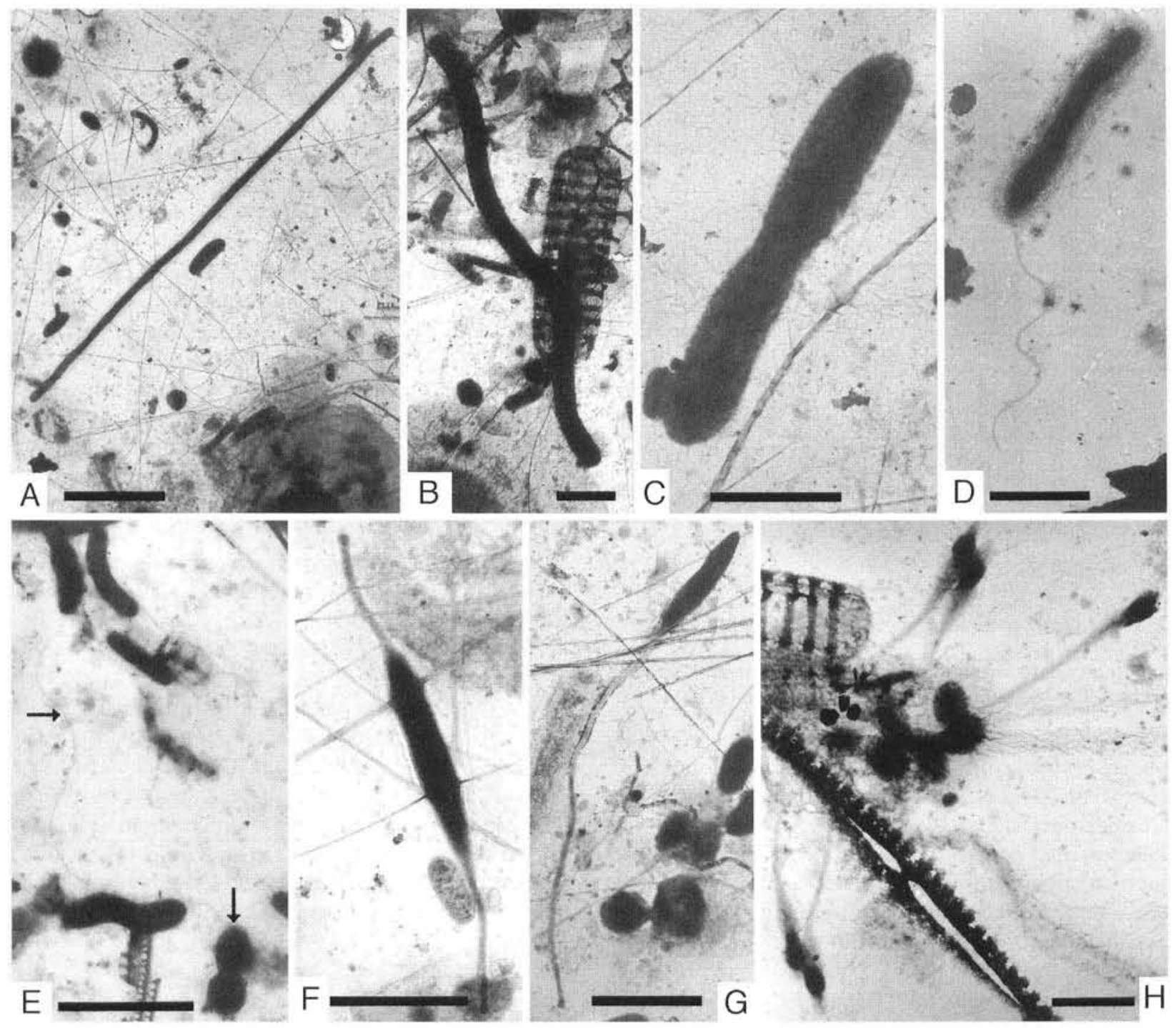

Fig. 5. Transmission electron micrographs of bacteria in sea-ice microbial communities (Stn 09/297). (A, B) Long bacterial cells, (C) thick, dividing bacterium, (D) flagellated bacterium with slime sheath, (E) differently shaped bacteria, among others a flagellated and a dividing bacterium, $(F, G, H)$ bacteria with appendages, $(\mathrm{H})$ appendaged bacteria attached on algal detritus. Scale bar $=5 \mu \mathrm{m}$ in $(\mathrm{A})$ and $2 \mu \mathrm{m}$ in $(\mathrm{B})$ to $(\mathrm{H})$

factor applied was derived from growing cultures (Karl 1980), a poor physiological state of these bacterial assemblages has to be assumed.

The other ice-core samples yielded bacterial ATP values which constituted between 7 and $70 \%$ (on average $34 \%$ ) of the total ATP (Fig. 6). The conversion factor is appropriate here as indicated by the correspondence between calculated bacterial ATP, sizefractionated ATP, and size-class pattern. The measured total ATP of the $>0.2$ to $3 \mu \mathrm{m}$ size fraction, for instance, makes up a similar percentage of the calculated bacterial ATP as is the case with the biovolume of the small size classes $\left(<1.33{\left.\mu \mathrm{m}^{3}\right)}^{3}\right.$ and the total bacterial biovolume (Figs. 3 \& 6). Small deviations occur due to the relatively high abundance of small appendaged bacteria attached to algal debris (Fig. $5 \mathrm{H}$ ).

\section{Viable counts}

The number of culturable heterotrophic bacteria obtained with different culture approaches is given in Table 2. The MPN method yielded estimates of viable bacterial numbers on average 6 times higher than the spread plate technique and 60 times higher than the membrane filter method. Maximum viable counts were recorded on Chitin agar $100 \%$ SW whereas low numbers of CFUs developed on Chitin agar $300 \%$ SW. 
Table 1. Bacterial biomass (based on direct microscopic biovolume estimates) and total particulate ATP of sea-ice and seawater samples. nd: not determined

\begin{tabular}{|c|c|c|c|c|c|c|c|c|c|}
\hline \multirow[t]{3}{*}{$\begin{array}{l}\text { Ice core } \\
\text { no. }\end{array}$} & \multirow{3}{*}{$\begin{array}{l}\text { Total } \\
\text { ice-core } \\
\text { depth } \\
\text { (m) }\end{array}$} & \multicolumn{3}{|c|}{$\begin{array}{l}\text { Bacterial biomass } \\
\quad\left(\mathrm{mg} \mathrm{C} \mathrm{m}^{-2}\right)\end{array}$} & \multirow{3}{*}{$\begin{array}{l}\text { Height of water } \\
\text { column accomo- } \\
\text { dating bacterial } \\
\text { biomass equi- } \\
\text { valent to that } \\
\text { of the over- } \\
\text { lying sea ice } \\
\text { (m) }\end{array}$} & \multicolumn{3}{|c|}{$\begin{array}{c}\text { Total particulate ATP } \\
\left(\mu \mathrm{g} \mathrm{m}^{-2}\right)\end{array}$} & \multirow{3}{*}{$\begin{array}{l}\text { Height of water } \\
\text { column accomo- } \\
\text { dating total partic- } \\
\text { ulate ATP equi- } \\
\text { valent to that } \\
\text { of the over- } \\
\text { lying sea ice } \\
\text { (m) }\end{array}$} \\
\hline & & \multirow[t]{2}{*}{ Sea ice } & \multicolumn{2}{|c|}{ Sea water } & & \multirow[t]{2}{*}{ Sea ice } & \multicolumn{2}{|c|}{ Sea water } & \\
\hline & & & $\begin{array}{l}\text { (Surface wa- } \\
\text { ter integra- } \\
\text { ted over ice- } \\
\text { core depth) }\end{array}$ & $\begin{array}{c}\text { (Integrated } \\
\text { over } 100 \mathrm{~m} \\
\text { water } \\
\text { depth) }\end{array}$ & & & $\begin{array}{l}\text { (Surface wa- } \\
\text { ter integra- } \\
\text { ted over ice- } \\
\text { core depth) }\end{array}$ & $\begin{array}{l}\text { (Integrated } \\
\text { over } 100 \mathrm{~m} \\
\text { water } \\
\text { depth) }\end{array}$ & \\
\hline 52202 & 0.76 & 1.7 & 2.8 & 222 & 0.8 & 47.2 & 0.8 & 104 & 45.4 \\
\hline 52205 & 0.62 & 2.0 & 1.6 & 195 & 1.0 & 8.8 & 4.4 & 328 & 2.7 \\
\hline 52207 & 0.92 & 51.0 & nd & $220^{a}$ & $23.1^{\mathrm{a}}$ & 551.2 & nd & $248^{b}$ & $222.2^{b}$ \\
\hline 52214 & 0.84 & 6.5 & 3.1 & 221 & 2.9 & 142.0 & 3.6 & 256 & 55.5 \\
\hline 52221 & 0.60 & 0.5 & 2.1 & 219 & 0.2 & 11.6 & 3.6 & 300 & 3.8 \\
\hline 52226 & 0.52 & 0.5 & 1.0 & 180 & 0.3 & 2.4 & 0.8 & 152 & 1.6 \\
\hline 52231 & 1.01 & 69.0 & nd & $220^{a}$ & $31.3^{a}$ & 377.6 & nd & $248^{b}$ & $152.3^{b}$ \\
\hline 52232 & 0.99 & 157.0 & 3.6 & 223 & 70.4 & 3312.0 & 3.6 & 240 & 1380.0 \\
\hline 52248 & 0.48 & 1.2 & 2.9 & 283 & 0.4 & 37.2 & 10.0 & 1560 & 2.4 \\
\hline
\end{tabular}

Extremely few bacterial colonies were obtained on freshwater medium (Chitin agar $0 \% \mathrm{SW}$ ), indicating salt requirements of the bacterial ice consortia tested. On the other hand, these bacteria were able to survive short-term salinity reductions. Experiments with 4 different ice cores demonstrated that sea ice melted without any addition of seawater (final salinity 5 to $10 \%$ ) yielded similar viable counts on Chitin agar $100 \%$ SW as did sea-ice samples melted in an equal volume of seawater (final salinity 20 to $23 \%$ ).

A comparison between viable and total bacterial counts revealed that a large number of bacteria from consolidated ice floes were able to propagate on solid agar and especially in liquid medium (Table 2). While the ratio of viable to total bacterial counts of natural samples is in general $1 \%$ or less, the proportion of reproducing bacteria clearly exceeded $1 \%$ in the majority of sea-ice samples. Some middle and nearbottom ice-core samples had more than $10 \%$, and 1 MPN series even $87 \%$. However, some upper ice layers, one bottom ice sample as well as nilas ice had percentages below 1\% (Table 2). Young pancake and grease ice displayed ratios even less than $0.1 \%$ (Table 2, Fig. 4).

The water samples beneath the consolidated ice floes yielded about $0.3 \%$ viable relative to total bacterial counts. Towards the ice-edge area, the ratios decreased and at last attained values of almost zero (Table 2). Thus, the already low proportions of culturable bacteria in the young grease and pancake ice exceeded those in the surrounding water (Table 2, Fig. 4).

\section{Temperature tolerance}

A collection of strains isolated from the various habitats were examined for temperature adaptation. Psychrophilic as well as facultatively psychrophilic growth responses were obtained. The psychrophilic and facultatively psychrophilic bacteria differed clearly in their temperature maxima and optima, whereas their temperature minima were quite similar. About $80 \%$ of both psychrophiles and facultative psychrophiles were able to grow down to $-5^{\circ} \mathrm{C}$ (Fig. 7 b) with insignificantly different generation times (Fig. 8). In spite of this marked tolerance towards low temperatures in both bacterial groups, clear differences became evident in their distribution (Fig.7a). More than $90 \%$ of the isolates from consolidated sea ice showed a psychrophilic/stenothermic growth response. Only a negligible portion of isolates $(9 \%)$ grew beyond $30^{\circ} \mathrm{C}$. Sixty percent of these facultatively psychrophilic sea-ice isolates originated from upper ice-core sections.

Newly formed grease ice and young pancake ice (about $2 \mathrm{~cm}$ thick) were colonized exclusively by facultatively psychrophilic bacteria. An older pancake ice floe (about $15 \mathrm{~cm}$ thick, Stn 09/400) as well as the ice core 52248 sampled near the ice edge were already occupied by a marked proportion of psychrophilic bacteria, indicating a successive increase of psychrophiles with the age of ice. Like young sea ice, the water beneath the consolidated ice harboured almost exclusively facultative psychrophiles. At lower latitudes (south of $65^{\circ} \mathrm{S}$ ) a slight increase of psychrophiles in the water was observed (Fig. 7a). 

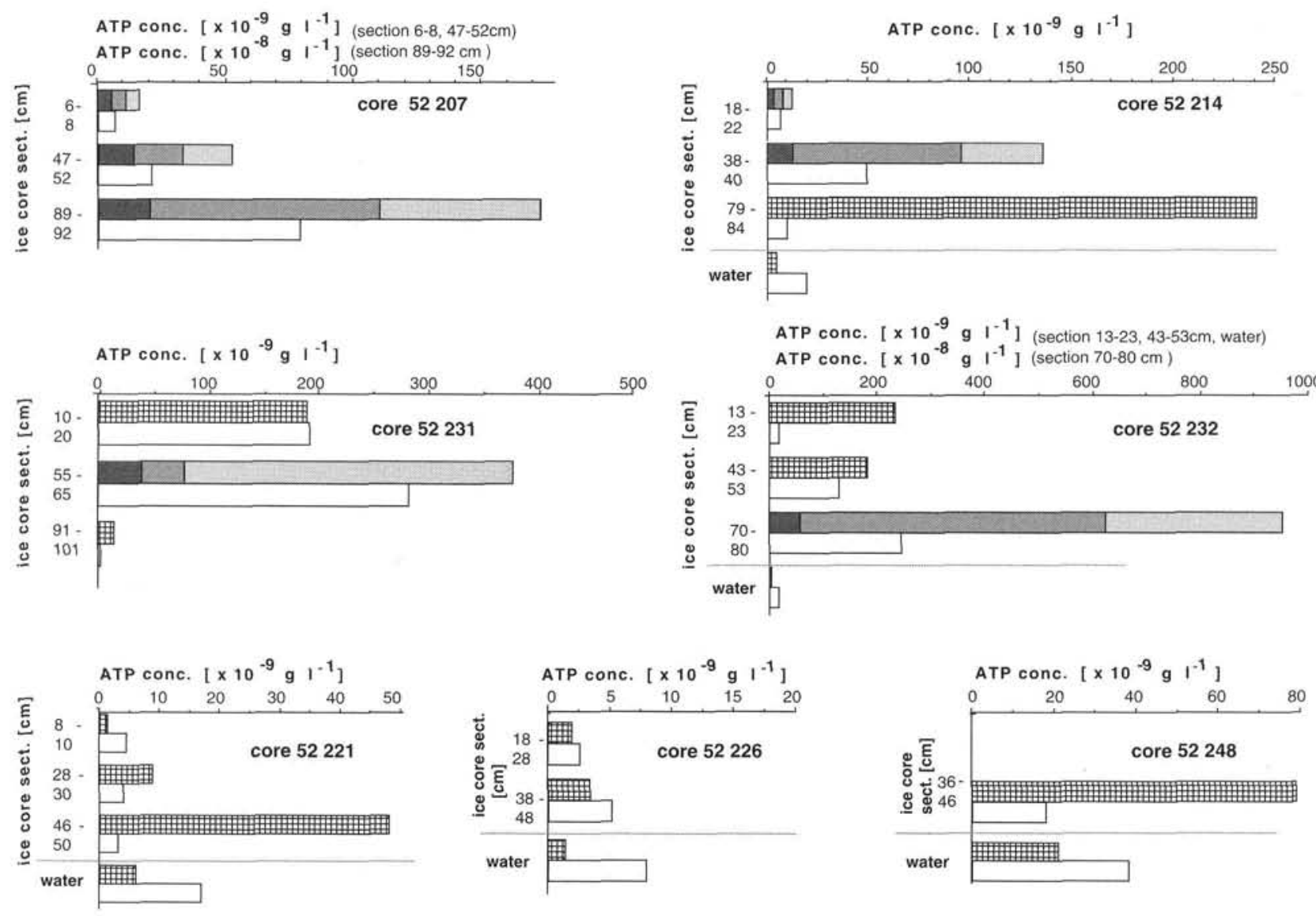

\section{Ice edge stations}
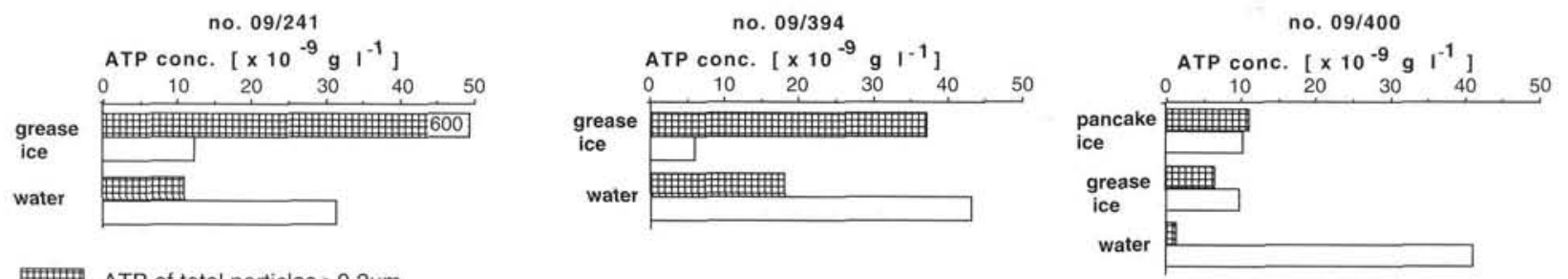

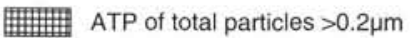

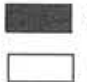

$0.2-3 \mu \mathrm{m}$ $3-12 \mu \mathrm{m}$ $>12 \mu \mathrm{m}$

ATP of size fractionated particles calculated bacterial ATP (bacterial biomass multiplied by a factor of 0.004 )

Fig. 6. Total ATP of ice-core sections, young ice, and underlying water in relation to calculated bacterial ATP. Note different scales on ordinates

\section{Turnover of monomeric substrates and secondary production}

To evaluate the influence of sea-ice preparation on the turnover times of monomeric substances, different ice treatments were tested (Table 3 ). The methods applied yielded turnover times which differed by more than 1 order of magnitude. These variations were particularly due to problems with the diffusion of the tracer towards the sites of heterotrophic activities (soaking of sea ice cubes, Method 1) as well as to the small salinity tolerance spectrum of the sea-ice bacteria (melting without seawater addition, Method 4). Satisfactory replicates and short turnover times were obtained with Methods 2 and 3 . Method 2 was routinely employed since a homogeneous distribution of the tracer is achieved; concurrently, sea-ice structure and thereby salinity conditions are maintained to a satisfactory degree. 
Table 2. Viable counts of ice edge samples, consolidated sea ice, and underlying water. SW: seawater content; MPN: most probable number; nd: not determined

\begin{tabular}{|c|c|c|c|c|c|c|c|}
\hline \multirow[t]{2}{*}{$\begin{array}{c}\text { Ice core } \\
\text { no. }\end{array}$} & \multirow[t]{2}{*}{$\begin{array}{l}\text { Ice class or } \\
\text { core section }\end{array}$} & \multicolumn{2}{|c|}{$\begin{array}{l}\text { Chitin agar } \\
100 \% \mathrm{SW}\end{array}$} & \multirow{2}{*}{\multicolumn{2}{|c|}{$\begin{array}{c}\text { Chitin agar Chitin agar } \\
300 \% \text { SW } 0 \% \text { SW } \\
\text { Viable counts } \\
\left(\mathrm{ml}^{-1}\right)\end{array}$}} & \multicolumn{2}{|c|}{$\begin{array}{l}\text { ZoBell broth } \\
100 \% \text { SW }\end{array}$} \\
\hline & & $\begin{array}{c}\text { Viable } \\
\text { counts }\left(\mathrm{ml}^{-1}\right)\end{array}$ & $\begin{array}{l}\text { Viable/total } \\
\text { counts (\%) }\end{array}$ & & & $\begin{array}{l}\text { MPN } \\
\left(\mathrm{ml}^{-1}\right)\end{array}$ & $\begin{array}{l}\text { MPN/total } \\
\text { counts }(\%)\end{array}$ \\
\hline \multicolumn{8}{|c|}{ Exterior ice edge zone } \\
\hline \multirow[t]{2}{*}{ 09/394 } & Grease ice & 0.6 & 0.001 & nd & nd & 36 & 0.09 \\
\hline & Water & 0 & 0 & nd & nd & 0.9 & 0.0004 \\
\hline \multirow[t]{3}{*}{$09 / 400$} & Grease ice & 33 & 0.05 & nd & 0 & 316 & 0.46 \\
\hline & Old pancake floe & 2773 & 3.70 & nd & 0 & 3750 & 5.0 \\
\hline & Water & 0 & 0 & nd & 0 & 4 & 0.002 \\
\hline \multirow[t]{2}{*}{$09 / 423$} & Pancake ice & 35.6 & 0.02 & 1 & 1 & 16 & 0.01 \\
\hline & Water & 0.3 & 0 & 2 & 2 & 5 & 0.003 \\
\hline \multicolumn{8}{|c|}{ Beginning of interior ice zone } \\
\hline \multirow[t]{3}{*}{52202} & $8-10 \mathrm{~cm}$ & 20 & 0.08 & 0 & 0 & nd & nd \\
\hline & $71-73 \mathrm{~cm}$ & 750 & 2.20 & 0 & 0 & nd & nd \\
\hline & Water & 30 & 0.04 & 40 & 0 & nd & nd \\
\hline \multirow[t]{4}{*}{52205} & $8-10 \mathrm{~cm}$ & 30 & 0.23 & nd & nd & nd & nd \\
\hline & $28-30 \mathrm{~cm}$ & 1630 & 6.79 & nd & nd & nd & nd \\
\hline & $60-65 \mathrm{~cm}$ & 60 & 0.32 & nd & nd & nd & nd \\
\hline & Water & 0 & 0 & nd & nd & nd & nd \\
\hline \multirow[t]{2}{*}{52248} & $36-46 \mathrm{~cm}$ & 714 & 1.86 & 2 & 22 & 6000 & 12.4 \\
\hline & Water & 190 & 0.12 & 290 & 20 & 190 & 0.2 \\
\hline \multicolumn{8}{|c|}{ Consolidated ice zone } \\
\hline \multirow[t]{3}{*}{52207} & $6-8 \mathrm{~cm}$ & 2090 & 8.30 & 30 & 0 & nd & nd \\
\hline & $47-52 \mathrm{~cm}$ & 53800 & 15.60 & 31800 & 0 & nd & nd \\
\hline & $89-92 \mathrm{~cm}$ & 322000 & 14.30 & 16800 & nd & 1900000 & 84.4 \\
\hline \multirow[t]{2}{*}{52210} & $30-40 \mathrm{~cm}$ & 350 & nd & nd & nd & nd & nd \\
\hline & Water & 50 & nd & nd & nd & nd & nd \\
\hline \multirow[t]{5}{*}{52214} & $18-22 \mathrm{~cm}$ & 1163 & 3.25 & 120 & 0 & 1900 & 5.3 \\
\hline & $38-40 \mathrm{~cm}$ & 57466 & 81.80 & 3900 & 0 & nd & nd \\
\hline & $69-71 \mathrm{~cm}$ & 50000 & 40.90 & 230 & 0 & nd & nd \\
\hline & $79-84 \mathrm{~cm}$ & 14300 & 29.01 & nd & nd & 43000 & 87.2 \\
\hline & Water & 270 & 0.35 & nd & nd & nd & nd \\
\hline \multirow[t]{4}{*}{52221} & $8-10 \mathrm{~cm}$ & 50 & 0.29 & 0 & 0 & 150 & 0.9 \\
\hline & $28-30 \mathrm{~cm}$ & 760 & 5.67 & 0 & 0 & 500 & 3.5 \\
\hline & $46-50 \mathrm{~cm}$ & 1685 & 12.90 & 10 & 0 & 9000 & 69.0 \\
\hline & Water & 130 & 0.30 & 90 & 20 & nd & nd \\
\hline \multirow[t]{3}{*}{52226} & $18-28 \mathrm{~cm}$ & 118 & 0.80 & nd & nd & nd & nd \\
\hline & $38-48 \mathrm{~cm}$ & 190 & 1.32 & nd & nd & nd & nd \\
\hline & Water & 170 & 0.20 & nd & nd & nd & nd \\
\hline \multirow[t]{3}{*}{52231} & $10-20 \mathrm{~cm}$ & nd & nd & 6965 & 41 & nd & nd \\
\hline & $55-65 \mathrm{~cm}$ & 145555 & 28.00 & 4236 & 5 & 102000 & 19.3 \\
\hline & $91-101 \mathrm{~cm}$ & 1176 & 12.50 & 20 & 0 & nd & nd \\
\hline 52232 & $13-23 \mathrm{~cm}$ & 23575 & 35.00 & 6351 & 0 & 43000 & 65.2 \\
\hline & $43-53 \mathrm{~cm}$ & 33407 & 20.20 & 6858 & 22 & 110000 & 68.7 \\
\hline & $70-80 \mathrm{~cm}$ & 816477 & 4.56 & 26013 & 0 & 1041000 & 5.8 \\
\hline & Water & 220 & 0.29 & nd & nd & nd & nd \\
\hline 52239 & $10-20 \mathrm{~cm}$ & 1086 & 3.10 & nd & nd & nd & nd \\
\hline & $30-40 \mathrm{~cm}$ & 6432 & 5.50 & nd & nd & nd & nd \\
\hline & $60-70 \mathrm{~cm}$ & 1006 & 1.58 & nd & nd & nd & nd \\
\hline 52244 & $17-27 \mathrm{~cm}$ & 1483 & 8.60 & 40 & 10 & 10000 & 58.1 \\
\hline & $53-63 \mathrm{~cm}$ & 14584 & 7.00 & 0 & 0 & 100000 & 46.5 \\
\hline & $73-83 \mathrm{~cm}$ & 7322 & 8.96 & 46 & 1 & 38000 & 45.6 \\
\hline
\end{tabular}




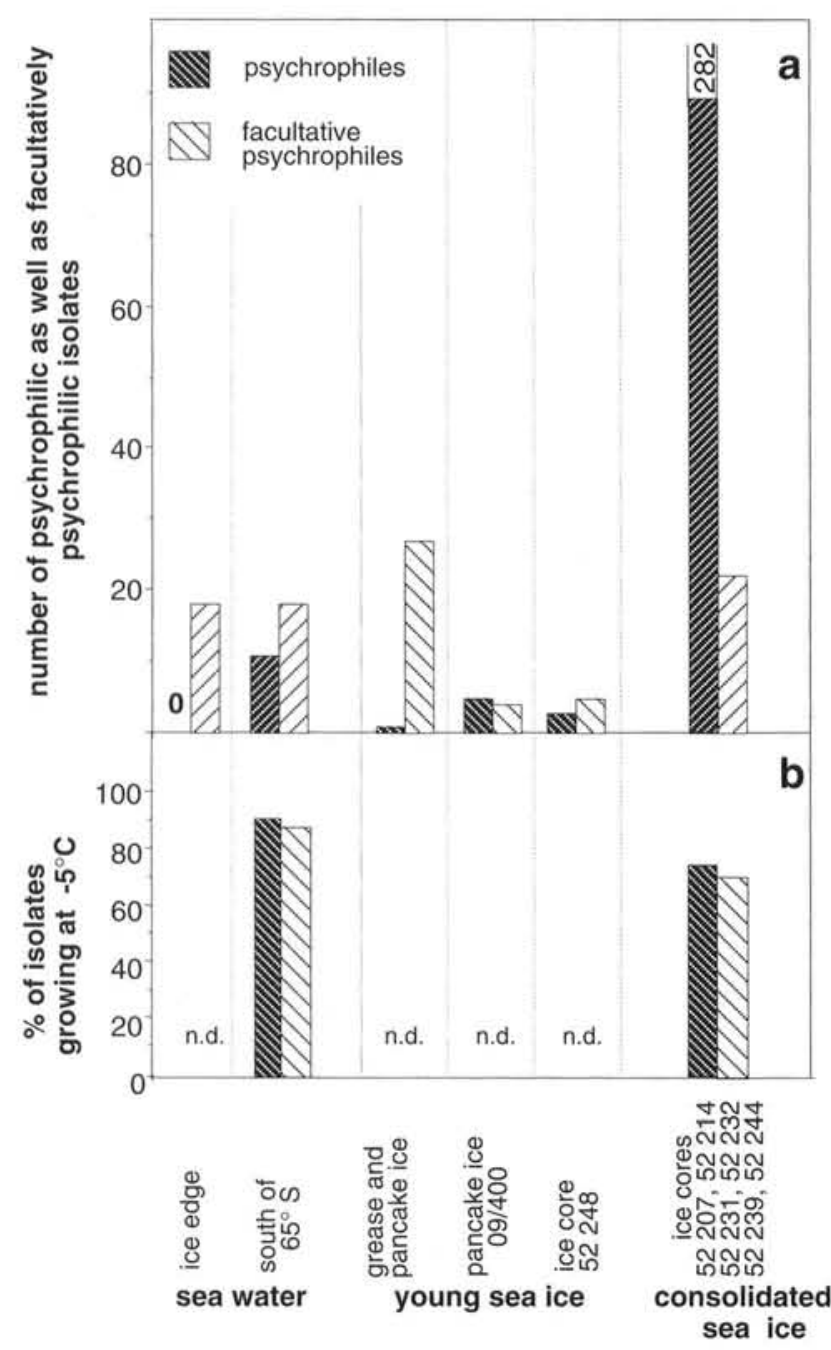

Fig. 7. (a) Portions of psychrophilic and facultatively psychrophilic strains of the isolates from different environments. (b) Percentages of psychrophilic and facultatively psychrophilic strains growing at $-5^{\circ} \mathrm{C}$

The leucine and glucose turnover data of various sea-ice and water samples are compiled in Table 4. Since respiration was not considered, an underestimation of about $30 \%$ for ${ }^{14} \mathrm{C}$-glucose turnover (Gocke 1976) and about $10 \%$ for ${ }^{3} \mathrm{H}$ leucine (Gocke 1976, Kuparinen \& Tamminen 1982) has to be taken into account. The different pack-ice communities assimilated glucose and leucine at $-2^{\circ} \mathrm{C}$. Turnover times ranged from a few days to $3 \mathrm{mo}$ in densely populated sea-ice material and extended to about $1 \mathrm{yr}$ in sparsely inhabited ice-core samples. The data correlated closely with viable as well as total counts (Table 4) (correlation

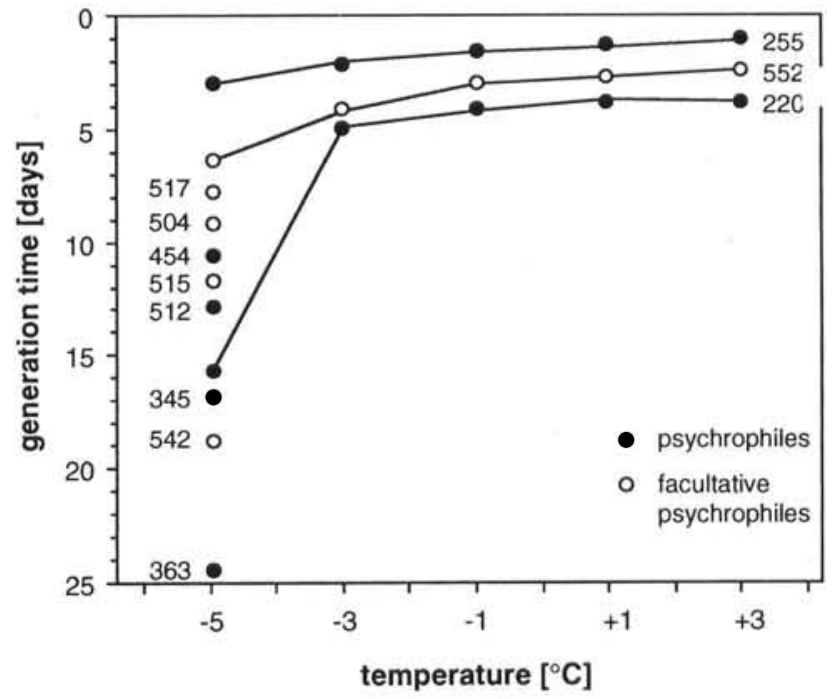

Fig. 8. Generation times of various psychrophilic and facultatively psychrophilic isolates from sea ice (bacterial strain nos. $220,255,345,363,454,512,542$ from grease ice, 552 pancake ice) and water (strain nos. 504, 515, 517) in the very low temperature range at high substrate concentrations

factors are in the range of $\mathrm{r}^{2}=0.76$ for leucine and $\mathrm{r}^{2}=$ 0.81 for glucose). The water beneath the ice showed very low heterotrophic activities, whereas water from an ice free area south of the Antarctic Convergence (west of Bouvet Island, samples were taken before entering the ice area) had leucine turnover times (at $2^{\circ} \mathrm{C}$ ) similar to densely populated ice-core sections (Table 4). Heterotrophic activity associated with seaice algae were tested by means of antibiotic inhibition experiments. The prokaryotic inhibitor chloramphenicol strongly affected leucine assimilation, whereas the eukaryotic inhibitor cycloheximide caused negligible effects (Table 4). Both antibiotics are specific proteinsynthesis inhibitors, therefore, a similar clear inhibition

Table 3. Influence of different sea-ice preparations on the turnover time of ${ }^{3} \mathrm{H}$-leucine. nd: not determined

\begin{tabular}{|lccccc|}
\hline $\begin{array}{l}\text { Method of } \\
\text { preparing } \\
\text { ice sample }\end{array}$ & $\begin{array}{c}\text { Brash ice } \\
09 / 297\end{array}$ & $\begin{array}{c}\text { Ice core } \\
52223\end{array}$ & $\begin{array}{c}\text { Ice core } \\
52226\end{array}$ & $\begin{array}{c}\text { Ice core } \\
52231\end{array}$ & $\begin{array}{c}\text { Ice core } \\
52232\end{array}$ \\
\hline $\begin{array}{l}\text { (1) Crushed ice } \\
\begin{array}{l}\text { (2) Crushed ice sus- } \\
\text { pended in seawater }\end{array}\end{array}$ & 141 & 9980 & 2138 & 1179 & 472 \\
$\begin{array}{l}\text { (3) Ice melted in } \\
\text { seawater }\end{array}$ & 15.5 & 399 & 658 & nd & nd \\
$\begin{array}{l}\text { (4) Ice melted without } \\
\text { added seawater }\end{array}$ & 224 & 8317 & 1425 & 3305 & nd \\
\hline
\end{tabular}


Table 4. Turnover times of ${ }^{3} \mathrm{H}$-leucine and ${ }^{14} \mathrm{C}$-glucose in ice core and water samples. nd: not determined

\begin{tabular}{|c|c|c|c|c|c|c|c|c|}
\hline \multirow[t]{3}{*}{ Sample } & \multicolumn{6}{|c|}{ Turnover time (d) } & \multirow{2}{*}{\multicolumn{2}{|c|}{$\begin{array}{l}\text { Bacterial counts } \\
\quad\left(\times 10^{3} \mathrm{ml}^{-1}\right)\end{array}$}} \\
\hline & \multirow[t]{2}{*}{ Leucine } & \multirow{2}{*}{$\begin{array}{l}\text { Leucine } \\
+ \text { chloram- } \\
\text { phenicol }\end{array}$} & \multirow{2}{*}{$\begin{array}{l}\text { Leucine } \\
\text { + cyclo- } \\
\text { heximide }\end{array}$} & \multirow[t]{2}{*}{ Glucose } & \multirow{2}{*}{$\begin{array}{l}\text { Glucose } \\
+ \text { chloram- } \\
\text { phenicol }\end{array}$} & \multirow{2}{*}{$\begin{array}{l}\text { Glucose } \\
\text { + cyclo- } \\
\text { heximide }\end{array}$} & & \\
\hline & & & & & & & Total & Viable \\
\hline \multicolumn{9}{|l|}{ Brown ice floe: } \\
\hline Stn $09 / 297$ & $15.5^{\mathrm{a}}$ & nd & nd & $14.4^{\mathrm{b}}$ & & & 15000 & nd \\
\hline \multicolumn{9}{|l|}{ Ice core section: } \\
\hline 52223 , near bottom & 332 & nd & nd & nd & & & 18 & 0.15 \\
\hline 52226 , near bottom & 356 & nd & nd & nd & & & 15 & 0.19 \\
\hline 52231 , middle & 84 & 531 & 94 & 70 & & & 550 & 145.55 \\
\hline 52232 , near bottom & 9.5 & 237 & 12 & 2.5 & 5.0 & 2.9 & 2410 & 816.47 \\
\hline 52238 , near bottom & 430 & nd & nd & 173 & & & 59 & nd \\
\hline 52244 , top & 476 & 1919 & 609 & 3990 & & & 51 & 1.48 \\
\hline middle & 86 & 1427 & 135 & 315 & & & 210 & 14.58 \\
\hline near bottom & 78 & 4328 & 119 & 179 & & & 81 & 7.32 \\
\hline \multicolumn{9}{|c|}{ Water beneath ice core: } \\
\hline 52202 & 1166 & nd & nd & nd & & & 72 & 0.03 \\
\hline 52238 & 2366 & nd & nd & 1001 & & & 100 & 0.05 \\
\hline \multicolumn{9}{|l|}{ Surface water off } \\
\hline \multirow[t]{2}{*}{ Bouvet Island: } & 79 & 1234 & 107 & nd & & & nd & nd \\
\hline & \multicolumn{3}{|c|}{$\begin{array}{l}\text { Bacterial cell production } \\
\left(\times 10^{10} \text { cells } \mathrm{m}^{-3} \mathrm{~d}^{-1}\right)\end{array}$} & \multicolumn{3}{|c|}{$\begin{array}{l}\text { Bacterial carbon production } \\
\qquad\left(\mathrm{mg} \mathrm{C} \mathrm{m}^{-3} \mathrm{~d}^{-1}\right)\end{array}$} & & \\
\hline \multicolumn{9}{|l|}{ Ice core section: } \\
\hline 52214 , near bottom & \multicolumn{3}{|c|}{2.3} & \multicolumn{3}{|c|}{0.2} & 122 & 50.00 \\
\hline 52232 , near bottom & \multicolumn{3}{|c|}{13.6} & \multicolumn{3}{|c|}{2.7} & 2410 & 816.47 \\
\hline 52244 , middle & \multicolumn{3}{|c|}{3.8} & \multicolumn{3}{|c|}{0.3} & 210 & 14.58 \\
\hline
\end{tabular}

response after an $18 \mathrm{~h}$ incubation could not be expected with glucose assimilation. This was reduced to about $50 \%$ by chloramphenicol, but contrary to results of Smith \& Clement (1990), only to about $14 \%$ by cycloheximide. A significant contribution of eucaryotes to heterotrophic processes in winter sea ice is thus unlikely.

Incorporation of tritiated thymidine into cold TCA precipitate was used to estimate bacterial secondary production. Only densely populated sections of 3 different ice cores were analyzed. The calculated bacterial cell and carbon production ranged from 2.3 to 13.6 $\times 10^{10}$ cells $\mathrm{m}^{-3} \mathrm{~d}^{-1}$ and from 0.2 to $2.7 \mathrm{mg} \mathrm{C} \mathrm{m}^{-3} \mathrm{~d}^{-1}$, respectively (Table 4 ).

\section{Extracellular enzyme activities}

The potential to decompose particulate organic matter (POM) was investigated in sea-ice and water samples by means of fluorogenic model substrates. Activities of extracellular proteases, phosphatases, and $\alpha-$ and $\beta$-glucosidases could be shown at $1^{\circ} \mathrm{C}$ with all seaice samples tested (Table 5). Sea ice with low bacterial concentrations (core no. 53 210; 52 221) displayed relatively low extracellular activities, whereas the coloured ice section of core no. 52244 exhibited very short hydrolysis times and high maximal hydrolysis rates.

The limit of the sensitive fluorescence method was reached with water samples from beneath the sea ice (Tables $5 \& 6$ ), again indicating a severe reduction of biological activity in the water column beneath sea ice during winter.

The leu-MCA-protease as well as the MUF- $\beta$-glucosidase activities correlated closely with viable counts (Table 6). Corresponding with results from temperate waters (Hoppe 1983), MUF-phosphatase activities did not correlate with viable counts. These enzymes are also exceptional with respect to their temperature response. Temperature optima of MUF-phospatases were in the range of 50 to $60^{\circ} \mathrm{C}$ (Fig. 9) whereas leuMCA-proteases and MUF- $\alpha$ - and $\beta$-glucosidases displayed optima at about $30^{\circ} \mathrm{C}$. 
Table 5. Maximum velocity of hydrolysis $\left(V_{\max }, \mathrm{pmol} \mathrm{l}^{-1} \mathrm{~min}^{-1}\right)$ and hydrolysis times (d; according to Hoppe et al. 1988) of extracellular enzymes of different sea-ice core sampl_ assayed by means of fluorogenic substrate analogues at $1^{\circ} \mathrm{C}$. nd: not determined. See 'Methods; Extracellular enzyme activity' for enzyme names in full

\begin{tabular}{|c|c|c|c|c|c|c|c|c|c|}
\hline \multirow{2}{*}{$\begin{array}{l}\text { Ice core } \\
\text { Section } \\
(\mathrm{cm})\end{array}$} & \multirow{2}{*}{$\begin{array}{l}\text { Viable } \\
\text { counts } \\
\left(\mathrm{ml}^{-1}\right)\end{array}$} & \multicolumn{2}{|c|}{ Leu-MCA } & \multicolumn{2}{|c|}{ MUF-phos. } & \multicolumn{2}{|c|}{ MUF- $\alpha$-gluc. } & \multicolumn{2}{|c|}{ MUF- $\beta$-gluc. } \\
\hline & & $V_{\max }$ & $\begin{array}{l}\text { Hydrol. } \\
\text { time }\end{array}$ & $V_{\max }$ & $\begin{array}{l}\text { Hydrol. } \\
\text { time }\end{array}$ & $V_{\max }$ & $\begin{array}{l}\text { Hydrol. } \\
\text { time }\end{array}$ & $V_{\max }$ & $\begin{array}{l}\text { Hydrol. } \\
\text { time }\end{array}$ \\
\hline \multicolumn{10}{|l|}{52210} \\
\hline $30-40$ & 350 & 23.4 & 636 & 3.6 & 204 & nd & nd & nd & nd \\
\hline Water & 50 & 7.2 & 14300 & 1.5 & 812 & nd & nd & nd & nd \\
\hline \multicolumn{10}{|l|}{52221} \\
\hline $46-50$ & 1685 & 9.7 & 586 & 6.8 & 1023 & nd & nd & nd & nd \\
\hline \multicolumn{10}{|l|}{52244} \\
\hline $17-27$ & 1483 & 162.2 & 43 & 51.6 & 258 & nd & nd & nd & nd \\
\hline $53-63$ & 14584 & 1058.5 & 1.6 & 135.1 & 57 & 41.9 & 211 & 44.8 & 392 \\
\hline
\end{tabular}

Table 6. Hydrolysis rates of extracellular enzymes of different sections of 2 sea-ice cores as well as of the water beneath the ice related to viable counts (Chitin agar $100 \% \mathrm{SW}, 1^{\circ} \mathrm{C}$ ). The extracellular enzymatic activities of core 52244 were determined at $1^{\circ} \mathrm{C}$ with substrate concentrations of $12.9 \mu \mathrm{mol} \mathrm{l^{-1 }}$ leu-MCA and $12.4 \mu \mathrm{mol} 1^{-1}$ MUF-phosphate. The ice material of the poorly colonized ice core 52221 was assayed for extracellular enzymatic activities at $20^{\circ} \mathrm{C}$ with substrate concentrations of $8.6 \mu \mathrm{mol} 1^{-1}$ leu-MCA, $8.3 \mu \mathrm{mol} \mathrm{1^{-1 }}$ MUF-phosphate, and $16.7 \mu \mathrm{mol} 1^{-1}$ MUF- $\beta$-glucoside. $r^{2}$ : correlation between hydrolysis rates and viable counts of bacteria. nd: not determined

\begin{tabular}{|c|c|c|c|c|}
\hline \multirow{2}{*}{$\begin{array}{l}\text { Ice core } \\
\text { Section }(\mathrm{cm})\end{array}$} & \multirow{2}{*}{$\begin{array}{l}\text { Viable counts } \\
\qquad\left(\mathrm{ml}^{-1}\right)\end{array}$} & \multicolumn{3}{|c|}{ Hydrolysis rates $\left(\mathrm{pmol}^{-1} \mathrm{~min}^{-1}\right.$ ) } \\
\hline & & Leu-MCA & MUF-phos. & MUF- $\beta$-gluc. \\
\hline \multicolumn{5}{|l|}{52221} \\
\hline $8-10$ & 50 & 1.6 & 1.3 & 0.35 \\
\hline $28-30$ & 760 & 3.7 & 11.5 & 0.84 \\
\hline $46-50$ & 1685 & 8.0 & 11.0 & 1.66 \\
\hline \multirow[t]{2}{*}{ Water } & 130 & 2.5 & 15.8 & 0.28 \\
\hline & & $\mathrm{r}^{2}=0.97$ & $\mathrm{r}^{2}=0.06$ & $\mathrm{r}^{2}=0.98$ \\
\hline \multicolumn{5}{|l|}{52244} \\
\hline $17-27$ & 1483 & 89.6 & 38.6 & nd \\
\hline $53-63$ & 14584 & 851.1 & 54.9 & nd \\
\hline Water & 70 & $\begin{array}{c}0.5 \\
\mathrm{r}^{2}=0.99\end{array}$ & $\begin{array}{c}1.3 \\
r^{2}=0.63\end{array}$ & nd \\
\hline
\end{tabular}

(Kottmeier \& Sullivan 1990). Significant inhibition effects were not obvious in middle and lower ice-core zones, where temperatures ranged between -2.5 (bottom) and $-5.5^{\circ} \mathrm{C}$ (middle) (Weissenberger 1992). Maximal cell concentrations and microbial activities were determined in the lower part of the middle ice layers in sparsely as well as densely populated ice cores. In contrast to the major part of the sea ice the comparatively warmer water $\left(>-1.9^{\circ} \mathrm{C}\right)$ beneath the protecting ice cover was biologically impoverished. This is indicated by ATP concentrations, which were about 1 order of magnitude less (Fig. 6) than ATP concentrations reported in the surface water from other parts of the Southern Ocean during summer and autumn (Hodson et al. 1981, Hanson \& Lowery 1985, Vosjan et al. 1987), as well as by extremely low chlorophyll a ( $\mathrm{chl} \mathrm{a}$ ) values (in the range of 0.03 to $0.08 \mu \mathrm{g} \mathrm{I}^{-1}$; Bartsch 1989, Scharek

\section{DISCUSSION}

Bacterial processes within the sea ice during winter were expected to be severely inhibited by low temperatures and corresponding high brine salinities. However, a clear temperature-induced limitation of bacterial development was only evident in the upper ice layer where (dependent on snow cover) average temperatures of -7 to $-9^{\circ} \mathrm{C}$ and a minimum of $-15^{\circ} \mathrm{C}$ (Bartsch 1989) were recorded. The low bacterial concentrations and the poor viability found here contrast with the well developed and abundant surface assemblages observed during spring and summer (Garrison \& Buck 1989) as well as with the highly productive melt pond communities recorded during autumn et al. 1994). Heterotrophic activities (Table 4) were also at least 1 order of magnitude less compared to those determined in the marginal ice zone of the northwestern Weddell Sea during spring and autumn (Cota et al. 1990, Sullivan et al. 1990) but were similar to the very low values measured during summer beneath a consolidated ice cover in McMurdo Sound (Hodson et al. 1981). Viable bacterial counts (Table 2) were correspondingly low. These, however, contrasted with relatively high total bacterial abundances as well as bacterial biomass (Fig. 2, Table 1) which resembled values determined during spring and autumn in the marginal pack-ice zone of the western Weddell Sea (Kottmeier \& Sullivan 1990). In particular, the comparison of total and bacterial ATP values (Fig. 6) revealed that the high 


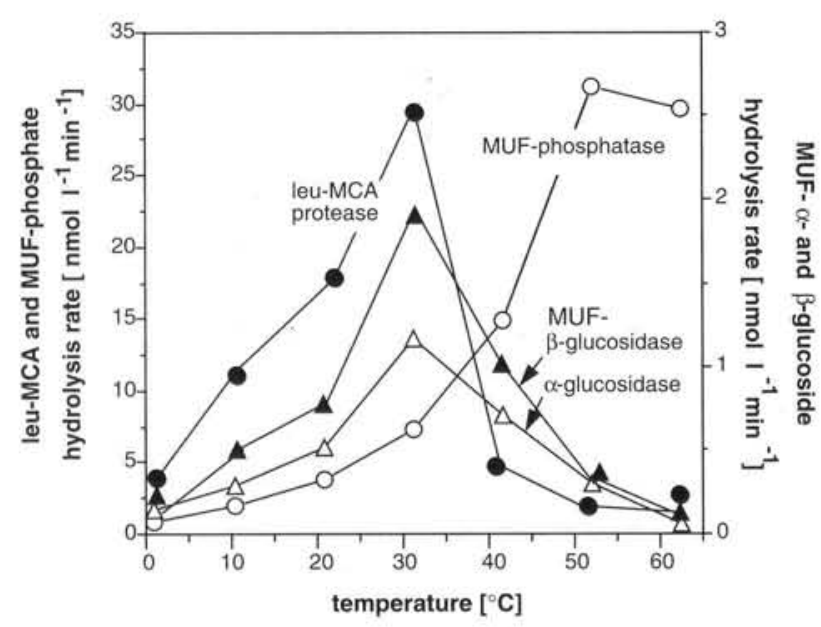

Fig. 9. Effect of temperature on the activity of extracellular enzymes of brown ice floe material (Stn 09/297) assayed by means of the dissolved methylumbelliferyl derivatives leuMCA $\left(8.63 \mu \mathrm{mol} \mathrm{1^{-1 }}\right)$, MUF-phosphate $\left(8.32 \mu \mathrm{mol} \mathrm{1^{-1 }}\right)$, MUF$\alpha$-D-glucopyranoside $\left(16.7 \mu \mathrm{mol} 1^{-1}\right)$ and MUF- $\beta$-D-glucopyranoside $\left(16.7 \mu \mathrm{mol} \mathrm{1}^{-1}\right)$

bacterial standing stock comprised largely starving and moribund bacterial cells which persist, presumably, due to a paucity of bacterivores. The bacterial biomass would have been misjudged if the AODC method, which fails to discriminate between active, starving, and dead cells, had been solely employed.

The water beneath fast ice (Kottmeier \& Sullivan 1987, Rivkin et al. 1989, Satoh et al. 1989, Matsuda et al. 1990) is also reported to have very little plankton in winter. On the other hand, considerable primary as well as secondary production was observed during this season underneath an unconsolidated pack-ice cover in the Bellingshausen Sea (Kottmeier \& Sullivan 1987). Obviously, the biological impoverishment of the water column in winter depends to a high degree on the consolidation of ice cover which limits light.

Annual sea-ice communities are recruited every year from seawater. While the initial stock of organisms in the sea ice depends on the abundance and composition of the microbial assemblages within the water column at the time and location of ice formation, the further fate of the sea-ice biota is strongly controlled by the course of the ice-floe development. Even adjacent floes may have evolved completely differently due to dynamic processes such as drifting, divergence, and rafting. In order to understand the development of the sea-ice biota, knowledge about the history of the floe studied is important. Systematic glaciological studies during the cruise ANT V/2 revealed that ice texture is indicative of the history of sea-ice formation and evolution (Lange et. al. 1989, 1990). A close connection between genetic ice classes and biological features became obvious in this study as well as elsewhere (Spindler et al. 1990, Dieckmann et al. 1991a, b). Thus, conclusions on the dynamics of the different members of the sea-ice community become possible in spite of the patchy horizontal distribution of microorganisms.

Similarities between the biological features of the poor winter water and of the sea ice were only found with the 'predominantly congelation ice' which develops in calm water of leads.

Most of the winter ice is formed in the turbulent water of the marginal ice zone with relatively high chl a concentrations. Physical concentration mechanisms such as 'harvesting' and 'scavenging' play an important role in inoculation of this 'predominantly frazil ice' (Ackley 1982, Garrison et al. 1983, 1989, Ackley et al. 1987). During ANT V/2, foraminifers as well as chl a concentrations in 'predominantly frazil ice' exceeded those in the underlying water. However, the further development of algae as well as foraminifers appeared to be limited in this ice category since algal nutrient concentrations did not change significantly and foraminiferal concentrations decreased towards the continent (Spindler et al. 1990, Dieckmann et al. 1991a). A physical enrichment of total bacterial cells in the sea ice of the ice edge was not encountered (Fig. 4), although, at a low level, viable bacterial counts in the ice exceeded those in the associated water (Fig. 4). This phenomenon may be explained by a selective harvesting of viable bacteria due to their attachment to larger nutritious particles such as algae or detritus. Results of ice formation experiments (Grossmann \& Gleitz 1993) corroborate this speculation, as bacteria were found to be enriched only in the presence of specific algae.

Even if viable bacteria may be preferentially enclosed in sea ice, the ratios of viable to total bacteria are strikingly low in these young sea-ice samples as well as in the adjacent water of the ice edge area (Table 2). The bulk of bacteria is obviously strongly affected by initial ice formation. A clear metabolic reduction during ice formation processes was also observed in simulated ice formation experiments (Grossmann \& Gleitz 1993) as well as in an ice edge study during late autumn (Grossmann \& Dieckmann 1994). However, in the present study the increase of culturable and psychrophilic bacteria with advancing age of ice presents evidence for a new formation of specific bacterial communities in sea ice. Correspondingly, Grossmann \& Dieckmann (1994) found an increase of leucine uptake from young to older sea ice.

The new organization of bacterial communities in the 'predominantly frazil ice' is obviously supported by the relatively high concentrations of POM harvested during initial ice formation at the ice edge. In contrast, bacterial assemblages did not develop in the likewise 
young 'predominantly congelation ice' which is formed in the impoverished water of leads. These observations correspond with the findings of Pomeroy et al. (1991) as well as Wiebe et al. (1992) that bacterial reproduction in the minimum temperature range depends strongly on higher substrate concentrations.

The densely populated ice floes belonged to the 'mixed ice class' and the 'mainly frazil ice class' which were already formed during autumn or the season before and occurred more frequently towards the continent. Chl a concentrations were high, and former and/or ongoing phototrophic activity was indicated by low silicate concentrations and sometimes complete exhaustion of algal nutrients (Dieckmann et al. 1991a). Bacterial counts and biomass reached also maximal values (Figs. 2 \& 5, Table 1). By means of a variety of methods it is substantiated that the bacterial accumulations within these ice floes do not solely derive from a passive physical incorporation of autumnal bacterial blooms, but could be traced back to selective bacterial growth within the ice. Floes of these 2 ice classes turned out to be sites of concentrated heterotrophic activity during the entire midwinter period. They are, in comparison to the 2 other genetic ice classes discussed, of great biological significance in the annual pack ice of the Weddell Sea during midwinter.

A mean bacterial production of $6.6 \times 10^{10}$ cells $\mathrm{m}^{-3} \mathrm{~d}^{-1}$ equivalent to $1.06 \mathrm{mg} \mathrm{C} \mathrm{m}^{-3} \mathrm{~d}^{-1}$ was calculated for the densely colonized ice layers in these floes (Table 4). This is up to 5 times less than the bacterial production determined in the dispersed winter ice of the Bellingshausen Sea (Kottmeier \& Sullivan 1987). Nevertheless, both winter estimates are within the broad range of spring and summer values determined in the water column and marginal ice zone of different regions of the Southern Ocean and in the bottom ice sections of the fast ice of McMurdo Sound (compiled by Kottmeier et al. 1987, Cota et al. 1990; ranges from undetectable to $24 \mathrm{mg} \mathrm{C} \mathrm{m}^{-3} \mathrm{~d}^{-1}$ ). Only autumnal melt pond communities (1094 $\mathrm{mg} \mathrm{C} \mathrm{m}^{-3} \mathrm{~d}^{-1}$; Kottmeier \& Sullivan 1990) clearly surpass this range.

A rough estimate of the magnitude of secondary production in the annual pack ice of the Weddell Sea during winter was obtained by a conservative calculation based on a $20 \mathrm{~cm}$ thick, densely populated, middle ice layer of the 'mainly frazil ice' and 'mixed ice' (these account for $26.2 \%$ and $19 \%$ respectively of the sea ice in the study area, after Lange et al. 1989). The comparatively poorly colonized 'predominantly frazil ice' and 'predominantly congelation ice' were neglected. A bacterial production of $4.05 \times 10^{10} \mathrm{~g} \mathrm{C}$ was calculated for a 3 mo winter period in the $4.7 \times 10^{6} \mathrm{~km}^{2}$ (Zwally et al. 1983) large study area which comprises $24 \%$ of the total area of the Antarctic sea-ice cover. The mean bacterial carbon production would amount to $95.6 \mu \mathrm{g} \mathrm{C} \mathrm{m}^{-2} \mathrm{~d}^{-1}$ and would account for $43 \%$ of the primary production of interior ice algal communities in the Antarctic Ocean $\left(0.016 \times 10^{14} \mathrm{~g} \mathrm{C} \mathrm{yr}^{-1}\right.$ per $20 \times 10^{6} \mathrm{~km}^{2}$; Legendre et al. 1992). This significant bacterial production as well as the relatively high proportion of bacterial ATP to total ATP (on average $34 \%$ ) indicates a substantial role of the heterotrophic bacterial component within the microbial sea-ice community during winter.

Productivity measurements in the unconsolidated pack ice of the Bellinghausen Sea (Kottmeier \& Sullivan 1987) as well as in the fast ice and water of the McMurdo Sound (Rivkin et al. 1989) also revealed that bacterial production amount to a substantial fraction of primary production during winter. An increasing importance of heterotrophy during winter can be explained by light limitation. Kottmeier \& Sullivan (1988) further found that bacterial production is favoured in comparison to primary production in the low temperature range. In addition, lysis of sea-ice algae, induced by nutrient exhaustion, will provide bacteria with increased amounts of organic nutrients, among others macromolecules. These, however, have to undergo extracellular enzymatic decomposition prior to incorporation as dissolved substances by bacteria. POM hydrolysing processes have not yet been studied in sea ice. Leu-MCA hydrolysis times were surprisingly short in densely populated ice cores (Tables $5 \& 6$ ). These values were comparable with data determined in eutrophic water samples of a temperate region (Hoppe 1983, Hoppe et al. 1988). POMdegradation, therefore, does not appear to be a limiting step in recycling organic carbon in densely populated sea-ice samples, even if a definite evaluation is difficult due to the uncertain analogous character of the fluorogenic substrates to natural substances (Hoppe 1983, Hoppe et al. 1988, Helmke \& Weyland 1991). However, a pronounced hydrolysis potential for natural polymers could also be demonstrated with a collection of 326 bacterial sea-ice isolates (authors' unpubl. results).

The leu-MCA-proteases and MUF- $\alpha-$ and $\beta$-glucosidases of sea ice had relatively low temperature optima and maxima (Fig. 9) compared to extracellular enzymes of Antarctic sediments (Helmke \& Weyland 1991). The sea-ice enzymes resembled those formed by psychrophilic bacteria which have optima and maxima 10 to $20^{\circ} \mathrm{C}$ lower than enzymes produced by mesophilic bacteria (Helmke \& Weyland 1991). Water samples from the North Sea which were populated by mesophilic bacteria showed extracellular enzyme reactions similar to those from sea ice. However, the $V_{\max }$ values in the low temperature range were on average higher with the sea-ice samples (Helmke \& Weyland 1991). The similarities between extracellular enzymes of temperate and cold habitats underline the 
generally broad tolerance spectrum of extracellular enzymes and corroborate the assumption that degradation of particulate matter is less controlled by a specific temperature adaptation of the extracellular enzymes per se than by the formation of the enzymes which is governed by the adaptation of the producers (Helmke \& Weyland 1986).

The bacterial sea-ice and seawater assemblages differed clearly in their temperature-adaptive strategies. Bacteria isolated from consolidated sea ice responded preponderantly stenothermic/ psychrophilic whereas those from water and young ice behaved eurythermic/facultatively psychrophilic. Since the percentage of culturable bacteria was extraordinarily high in older sea-ice samples, psychrophily has to be considered as the general adaptation concept in well-developed bacterial sea-ice assemblages. The proportion of culturable bacteria in the water beneath the ice as well as in young ice was $1 \%$ or less. Thus, the facultative psychrophiles studied might be less representative. A dominance of facultative psychrophiles (psychrotrophs) in sea-ice-associated water was also found in the western Weddell Sea during summer (Delille 1992). On the other hand, a strong partitioning between water and sea-ice communities, as found in the present study, was not encountered during a cruise in autumn where, in still unconsolidated pack ice of the eastern Weddell Sea, psychrophilic bacteria predominated in sea ice as well as in plankton-rich water (Helmke unpubl. obs.). This observation as well as the insignificantly different generation times of psychrophiles and facultative psychrophiles in the very low temperature range (Fig. 8) indicate that low temperatures alone could not account for the selective enrichment of psychrophiles. Salinity also cannot be taken into account as the relevant controlling factor since psychrophiles have a smaller salinity tolerance spectrum than facultative psychrophiles (authors' unpubl. results, partly indicated in this study by the viable count data as well as the heterotrophic activity data). Beside sea ice and plankton-rich Antarctic water, shallow Antarctic sediments also harbour bacterial communities predominated by psychrophilic bacteria (Helmke \& Weyland 1991) but with a different taxonomical structure (authors' unpubl. results). The 3 habitats are characterized by low temperatures as well as higher levels of organic matter mostly associated with increased solid surfaces. The selective enrichment of psychrophiles are obviously determined by the combined effect of these ecofactors. Competition experiments in continuous cultures at varying temperature and substrate conditions with psychrophilic and facultatively psychrophilic isolates from the North Sea (Harder \& Veldkamp 1971) corroborate our assumption based on observations in the field.
The present study gives evidence that temperature is generally not the major controlling factor for the development of active or inactive bacterial communities in the surface layer of the eastern Weddell Sea during midwinter. Sea ice in comparison to seawater turned out to be the preferred habitat of bacteria in spite of the exceptionally low temperatures and high salinities. Apparently, due to an improved availability of energy/ nutrient sources in sea ice, unique bacterial communities develop and propagate. Their contribution to the bacterial productivity in the Weddell Sea during winter is obviously substantial.

Acknowledgements. We thank J. Jürgens, C. Lorenzen, A. Schlüter, and H. Schwarz for skillful technical assistance. Our gratitude also extends to the officers, crew, and scientific staff of the RV 'Polarstern' for all kinds of assistance during the expedition. Many colleagues have contributed to the field work; their help, particularly that of S. Ackley and G. Dieckmann, is greatly appreciated. Special thanks are also due to the logistical support of R. Krause. G. Dieckmann is thanked for his constructive criticism of a draft version of this paper and for correcting the English manuscript. This is contribution no. 839 of the Alfred-Wegener-Institute for Polar and Marine Research.

\section{LITERATURE CITED}

Ackley, S. F. (1982). Ice scavenging and nucleation: two mechanisms for incorporation of algae into new forming sea ice. EOS 63: 54

Ackley, S. F., Dieckmann, G., Shen, H. (1987). Algal and foram incorporation into new sea ice. EOS 68: 1736

Assur, A. (1958). Composition of sea ice and its tensile strength. In: Antarctic sea ice, NRC Publ. 598. National Academy of Science, Washington, DC, p. 106-138

Bartsch, A. (1989). Die Eisflora des Weddellmeeres (Antarktis): Artenzusammensetzung und Biomasse sowie Ökophysiologie ausgewählter Arten. Ber. Polarforsch. 63: $1-110$

Bratback, G. (1985). Bacterial biovolume and biomass estimations. Appl. environ. Microbiol. 49: 1488-1493

Casarini, M. P., Massom, R. (eds.) (1987). Winter Weddell Sea Project; sea ice observations, leg 1: June-September 1986. Scott Polar Research Institute, University of Cambridge

Cota, G. F., Kottmeier, S. T., Robinson, D. H., Smith, W. O., Sullivan, C.W. (1990). Bacterial plankton in the marginal ice zone of the Weddell Sea: biomass, production and metabolic activities during austral autumn. Deep Sea Res. 37: $1145-1167$

Delille, D. (1992). Marine bacterioplankton at the Weddell Sea ice edge, distribution of psychrophilic and psychrotrophic populations. Polar Biol. 12: 205-210

Dieckmann, G. S., Lange, M. A., Ackley, S. F., Jennings, J. C. $\mathrm{Jr}$ (1991a). The nutrient status in sea ice of the Weddell Sea during winter: effects of sea ice texture and algae. Polar Biol. 11: 449-456

Dieckmann, G. S., Spindler, M., Lange, M. A., Ackley, S. F., Eicken, H. (1991b). Antarctic sea ice: a habitat for the foraminifer Neogloboquadrina pachyderma. J, foram. Res. 21: 182-189

Fuhrmann, J. A., Azam, F. (1982). Thymidine incorporation as 
a measure of heterotrophic bacterioplankton production in marine surface waters: evaluation and field results. Mar. Biol. 66: 109-120

Garrison, D. L., Ackley, S. F., Buck, K. R. (1983). A physical mechanism for establishing algal populations in frazil ice. Nature 306: 363-365

Garrison, D. L., Buck, K. R. (1989). The biota of Antarctic pack ice in the Weddell Sea and Antarctic peninsula regions. Polar Biol. 10: 211-219

Garrison, D. L., Close, A. R. (1993). Winter ecology of the sea ice biota in Weddell Sea pack ice. Mar. Ecol. Prog. Ser. 96: $17-31$

Garrison, D. L., Close, A. R., Reimnitz, E. (1989). Algae concentrated by frazil ice: evidence from laboratory experiments and field measurements. Antarct. Sci. 1: 313-316

Garrison, D. L., Sullivan, C. W., Ackley, S. F. (1986). Sea ice microbial communities in Antarctica. BioSci. 36: 243-250

Gocke, K. (1976). Respiration von gelösten organischen Verbindungen durch natürliche Mikroorganismen-Populationen. Ein Vergleich zwischen verschiedenen Biotopen. Mar. Biol. 35: 375-383

Grossi, S. M., Kottmeier, S. T., Sullivan, C. W. (1984). Sea ice microbial communities. III. Seasonal abundance of microalgae and associated bacteria, McMurdo Sound, Antarctica. Microb. Ecol. 10: 231-242

Grossmann, S., Dieckmann, G. S. (1994). Bacterial standing stock, activity, and carbon production during formation and growth of sea ice in the Weddell Sea, Antarctica. Appl. environ. Microbiol. 60: 2746-2753

Grossmann, S., Gleitz, M. (1993) Microbial responses to experimental sea-ice formation: implications for the establishment of Antarctic sea-ice communities. J. exp. mar. Biol. Ecol. 173: 273-289

Hanson, R. B., Lowery, H. K. (1985). Spatial distribution, structure, biomass, and physiology of microbial assemblages across the Southern Ocean frontal zones during the late austral winter. Appl. environ. Microbiol. 49: 1029-1039

Harder, W., Veldkamp, H. (1971). Competition of marine psychrophilic bacteria at low temperatures. Antonie van Leeuwenhoek 37: 51-63

Helmke, E., Weyland, H. (1986). Effect of hydrostatic pressure and temperature on the activity and synthesis of chitinases of Antarctic Ocean bacteria. Mar. Biol. 91: 1-7

Helmke, E., Weyland, H. (1991). Effect of temperature on extracellular enzymes occurring in permanently cold marine environments. Kieler Meeresforsch., Sonderh. 8: 198-204

Hobbie, J. E., Daley, R. J., Jasper, S. (1977). Use of Nuclepore filters for counting bacteria by fluorescence microscopy. Appl. environ. Microbiol. 33: 1225-1228

Hodson, R. E., Azam, F., Carlucci, A. F., Fuhrman, J. A., Karl, D. M., Holm-Hansen, O. (1981). Microbial uptake of dissolved organic matter in McMurdo Sound, Antarctica. Mar. Biol. 61: 89-94

Holm-Hansen, O. (1973). Determination of total microbial biomass by measurements of adenosine triphosphate. In: Stevenson, L. H., Collwell, R. R. (eds.) Estuarine microbial ecology. University of South Carolina Press, Columbia, p. 73-89

Hoppe, H.-G. (1983). Significance of exoenzymatic activities in the ecology of brackish water: measurements by means of methylumbelliferyl-substrates. Mar. Ecol. Prog. Ser. 11: 299-308

Hoppe, H.-G., Kim, S.-J,, Gocke, K. (1988). Microbial decomposition in aquatic environments: combined process of extracellular enzyme activity and substrate uptake. Appl. environ. Microbiol. 54: 784-790

Horner, R. A. (1985): Sea ice biota. CRC Press, Boca Raton

Horner, R. A., Ackley, S. F., Dieckmann, G. S., Gulliksen, B., Hoshiai, T., Legendre, L., Melnikov, I. A., Reeburgh, W. S., Spindler, M., Sullivan, C. W. (1992). Ecology of sea ice biota. 1. Habitat, terminology, and methodology. Polar Biol. 12: 417-427

Karl, D. M. (1980). Cellular nucleotide measurements and applications in microbial ecology. Microbiol. Rev. 44: 739-796

Kottmeier, S. T., McGrath-Grossi, S., Sullivan, C. W. (1987). Sea ice microbial communities. VIII. Bacterial production in annual sea ice of McMurdo Sound, Antarctica. Mar. Ecol. Prog. Ser. 35: 175-186

Kottmeier, S. T., Miller, M. A., Lizotte, M. P., Craft, L. L., Gulliksen, B., Sullivan, C. W. (1985). Ecology of sea ice microbial communities (SIMCO) during the 1984 winter to summer transition in McMurdo Sound. Antarctica. Antarct. J. U.S. 20: $128-130$

Kottmeier, S. T., Sullivan, C. W. (1987). Late winter primary production and bacterial production in sea ice and seawater west of the Antarctic Peninsula. Mar. Ecol. Prog. Ser. 36: $287-298$

Kottmeier, S. T., Sullivan, C. W. (1988). Sea ice microbial communities (SIMCO), 9. Effects of temperature and salinity on rates of metabolism and growth of autotrophs and heterotrophs. Polar Biol. 8: 293-304

Kottmeier, S. T., Sullivan, C. W. (1990). Bacterial biomass and production in pack ice of Antarctic marginal ice edge zones. Deep Sea Res. 37: 1311-1330

Kuparinen, J., Tamminen, T. (1982). Respiration of tritiated substrates in heterotrophic activity assays. Appl, environ. Microbiol. 43: 806-809

Lange, M. A., Ackley, S. F., Wadhams, P., Dieckmann, G. S., Eicken, H. (1989). Development of the sea ice in the Weddell Sea. Ann. Glaciol. 12: 92-96

Lange, M. A., Schlosser, P., Ackley, S. F., Wadhams, P., Dieckmann, G. S. (1990). ${ }^{18} \mathrm{O}$ concentrations in the sea ice of the Weddell Sea, Antarctica. J. Glaciol. 36: 315-323

Legendre, L., Ackley, S. F., Dieckmann, G. S., Gulliksen, B. Horner, R. A., Hoshiai, T., Melnikov, I. A., Reeburgh, W. S., Spindler, M., Sullivan, C. W. (1992). Ecology of sea ice biota. 1. Global significance. Polar Biol. 12: 429-444

Marra, J., Burckle, L. H., Ducklow, H. W. (1982) Sea ice and water column plankton distribution in the Weddell Sea in late winter. Antarct. J. U.S. 17: 111-112

Marten, S., Brandt, P. (1984). The organelle versus endosymbiont problem of Cyanophora paradoxa. In: Wiesner, W., Robinson, D. G., Starr, R. C. (eds.) Compartments in algal cells and their interaction. Springer-Verlag, Berlin, p. $69-75$

Matsuda, O., Ishikawa, S., Kawaguchi, K. (1990). Seasonal variation of particulate organic matter under the Antarctic fast ice and its importance to benthic life. In: Kerry, K. R., Hempel, G. (eds.) Antarctic ecosystems. Ecological change and conservation. Springer-Verlag, Berlin, p. $143-148$

Morita, R. Y. (1975). Psychrophilic bacteria. Bact. Rev. 39: 144-167

Palmisano, A. C., Garrison, D. L. (1993). Microorganisms in Antarctic sea ice. In: Friedmann, E. I. (ed.) Antarctic microbiology. Wiley-Liss, Inc., New York, p. 167-218

Pomeroy, L. R., Wiebe, W. J., Deibel, D., Thompson, R. J., Rowe, G. T., Pakulski, J. D. (1991). Bacterial responses to temperature and substrate concentration during the Newfoundland spring bloom. Mar. Ecol. Prog. Ser. 75: 143-159 
Raabe, W. (1987). Weather and synoptic situation during WWSP 1986 (ANT V/2). Ber. Polarforsch. 40: 1-161

Riemann, B., Fuhrmann, J., Azam, F. (1982). Bacterial secondary production in freshwater measured by ${ }^{3} \mathrm{H}$-thymidine incorporation method. Microb. Ecol. 8: 101-114

Rivkin, R. B., Putt, M., Alexander, S. P., Meritt, D., Gaudet, L. (1989). Biomass and production in polar planktonic and sea ice microbial communities: a comparative study. Mar. Biol. 101: 273-283

Rodina, A. G. (1972). Methods in aquatic microbiology. University Park Press, Baltimore, p. 172

Satoh, H., Fukumi, K., Watanabe, K, Takahashi, E. (1989). Seasonal changes in heterotrophic bacteria under fast ice near Syowa station, Antarctica. Can. J. Microbiol. 35: 329-333

Scharek, R., Smetacek, V., Fahrbach, E., Gordon, L. I., Rohardt, G., Moore, S. (1994). The transition from winter to early spring in the eastern Weddell Sea, Antarctica: plankton biomass and composition in relation to hydrography and nutrients. Deep Sea Res. (in press)

Smith, R. E. H., Clement, P. (1990). Heterotrophic activity and bacterial production in assemblages of microbes from sea ice in the high arctic. Polar Biol. 10: 351-357

Spindler, M., Dieckmann, G. S., Lange, M. A. (1990). Seasonal and geographic variations in sea ice community structure of the Weddell Sea, Antarctica. In: Kerry, K. R., Hempel, G. (eds.) Antarctic ecosystems. Ecological change and conservation. Springer-Verlag, Berlin, p. 129-135

Sullivan, C. W., Cota, G. F., Krempin, D. W., Smith, W. O. Jr (1990). Distribution and activity of bacterioplankton in the marginal ice zone of the Weddell-Scotia Sea during austral spring. Mar. Ecol. Prog. Ser. 63: 239-252

Sullivan, C. W., Palmisano, A. C., Kottmeier, S., McGrathGrossi, S., Moe, R. (1985). The influence of light on growth

This article was presented by G. Rheinheimer (Senior Editorial Advisor), Kiel, Germany and development of the sea-ice microbial community in McMurdo Sound. In: Siegfried, W. R., Condy, P. R., Laws, R. M. (eds.) Antarctic nutrient cycles and food webs. Proc of the 4th SCAR Symp. on Antarctic biology. SpringerVerlag, Berlin, p. 78-83

Vosjan, J. H., Nieuwland, G., Ernst, W., Bluszcz, T. (1987). Shipboard comparison of two methods of extraction and measurements of ATP applied to Antarctic water samples. Neth. J. Sea Res. 21: 107-112

Wadhams, P., Lange, M. A., Ackley, S. F. (1987). The ice thickness distribution across the Atlantic sector of the Antarctic Ocean in midwinter. J. geophys, Res. 92(C13): 14535-14552

Weissenberger, J. (1992). Die Lebensbedingungen in den Solekanälchen des antarktischen Meereises. Ber. Polarforsch. 111: 1-159

Weyland, H., Rüger, H.-J., Schwarz, H. (1970). Zur Isolierung und Identifizierung mariner Bakterien. Ein Beitrag zur Standardisierung und Entwicklung adäquater Methoden. Veröff. Inst. Meeresforsch. Bremerh. 12: 269-296

Wiebe, W. J., Sheldon, W. M. Jr, Pomeroy, L. R. (1992), Bacterial growth in the cold: Evidence for an enhanced substrate requirement. Appl. environ. Microbiol. 58: 359-364

Williams, P. J. L., Askew, C. (1968). A method of measuring the mineralization by microorganisms of organic compounds in seawater. Deep Sea Res. 15: 365-375

Zdanowsky, M. K., Donachie, S. P. (1993). Bacteria in the seaice zone between Elephant Island and the South Orkneys during the Polish sea-ice zone expedition (December 1988 to January 1989). Polar Biol. 13: 245-254

Zwally, H. J., Parkinson, C. L., Comiso, J. C. (1983). Variability of Antarctic sea ice and changes in carbon dioxide. Science 220: 1005-1012

Manuscript first received: March 30, 1994

Revised version accepted: September 30, 1994 